\title{
Integration of remote sensing data and surface observations to estimate the impact of the Russian wildfires over Europe and Asia during August 2010
}

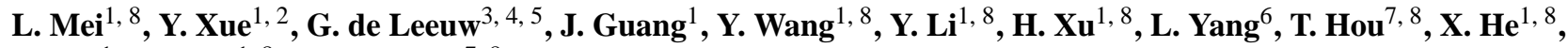 \\ C. Wu ${ }^{1}$, J. Dong ${ }^{1,8}$, and Z. Chen ${ }^{7,8}$ \\ ${ }^{1}$ State Key Laboratory of Remote Sensing Science, Jointly Sponsored by the Institute of Remote Sensing Applications of \\ Chinese Academy of Sciences and Beijing Normal University, Institute of Remote Sensing Applications, Chinese Academy \\ of Sciences, Beijing 100101, China \\ ${ }^{2}$ Faculty of Computing, London Metropolitan University, London N7 8DB, UK \\ ${ }^{3}$ Department of Physics, University of Helsinki, Helsinki, Finland \\ ${ }^{4}$ Finnish Meteorological Institute, Climate Change Unit, Helsinki, Finland \\ ${ }^{5}$ Netherlands Organisation for Applied Scientific Research TNO, Utrecht, The Nertherlands \\ ${ }^{6}$ School of Geography, Beijing Normal University, Beijing, China \\ ${ }^{7}$ Center for Earth Observation and Digital Earth of the Chinese Academy of Sciences, Beijing, China \\ ${ }^{8}$ Graduate University of the Chinese Academy of Sciences, Beijing, China
}

Received: 29 June 2011 - Published in Biogeosciences Discuss.: 3 August 2011

Revised: 19 October 2011 - Accepted: 14 November 2011 - Published: 21 December 2011

\begin{abstract}
A series of wildfires broke out in Western Russia starting in late July of 2010. Harmful particulates and gases released into the local Russian atmosphere have been reported, as have possible negative consequences for the global atmosphere. In this study, an extremely hazy area and its transport trajectory on Russian wildfires were analysed using aerosol optical depth (AOD) images retrieved via the synergy method from Moderate Resolution Imaging Spectroradiometer (MODIS) data. In addition, we used trace gases $\left(\mathrm{NO}_{2}\right.$ and $\mathrm{SO}_{2}$ ) and $\mathrm{CO}_{2}$ products measured using Ozone Monitoring Instrument (OMI) data, vertical distribution of AOD data retrieved from Cloud-Aerosol Lidar and Infrared Pathfinder Satellite Observation (CALIPSO) data, the mass trajectory analyses, synoptic maps from a HYSPLIT model simulation and ground-based data, including AERONET (both AOD and Ångström exponent) data and $\mathrm{PM}_{2.5}$. First, an Optimal Smoothing (OS) scheme was used to develop more precise and reliable AOD data based on multiple competing predictions made using several AOD retrieval models; then, integrated $\mathrm{AOD}$ and $\mathrm{PM}_{2.5}$ data were related using a chemical
\end{abstract}

transport model (GEOS-Chem), and the integrated AOD and visibility data were related using the $6 \mathrm{~S}$ radiative transfer code. The results show that the $\mathrm{PM}_{2.5}$ concentration is enhanced by a factor of 3-5 as determined from both satellite and in situ observations with peak daily mean concentrations of approximately $500 \mu \mathrm{g} \mathrm{m}^{3}$. Also, the visibility in many parts of Russia, for instance in Moscow, was less than 100 m; in some areas, the visibility was less than $50 \mathrm{~m}$. Additionally, the possible impact on neighbouring countries due to long-transport was analysed for 31 July and 15 August 2010. A comparison of the satellite aerosol products and ground observations from the neighbouring countries suggests that wildfires in Western Russian had little impact on most european and asian countries, the exceptions being Finland, Estonia, Ukraine and Kyrgyzstan. However, a possible impact on the Arctic region was identified; such an effect would have a serious influence on the polar atmospheric enviroment, and on animals such as polar bears.

Correspondence to: Y. Xue

(yxue@irsa.ac.cn)

Published by Copernicus Publications on behalf of the European Geosciences Union. 


\section{Introduction}

Biomass burning is the burning of living and dead vegetation. The total global burned area was an estimated 3.5 million $\mathrm{km}^{2}$ in the year 2000 (Tansey et al., 2008), 2.973.74 million $\mathrm{km}^{2}$ in 2001-2004 (Giglio et al., 2006), between 3.5 million $\mathrm{km}^{2}$ and 4.5 million $\mathrm{km}^{2}$ during 2005 and 2007 (Tansey et al., 2008) and between 3.3 and 4.31 million $\mathrm{km}^{2}$ in 2008 (Giglio et al., 2010). Biomass burning is known to be a major contributor to the global budgets of several trace gases and greenhouse gases, including carbon monoxide (CO) (Nam et al., 2010), $\mathrm{CO}_{2}$ (Freitas et al., 2005; Murdiyarso, 1993; Alleaume, 2005), $\mathrm{CH}_{4}$ (Alleaume, 2005) and nitrogen oxides $\left(\mathrm{NO}_{\mathrm{x}}=\mathrm{NO}+\mathrm{NO}_{2}\right)($ Bruzzone, 2003). It also contributes aerosol particles, which are a major source of volatile organic compounds and organic halogen compounds (Crutzen and Andreae, 1990; Trentmann et al., 2001; Freitas et al., 2005). Russian boreal forests are subject to frequent wildfires. Each year, 10-35 thousand forest fires covering $5000-53000 \mathrm{~km}^{2}$ (including $4000-10000 \mathrm{~km}^{2}$ of highintensity, stand-replacing fires) are detected in actively protected portions of the Russian forest (Bartalev et al., 1977; Isaev et al., 2002). Some authors estimate even larger figures of up to $100000-120000 \mathrm{~km}^{2}$ (Conard and Ivanova, 1988).

The implications of these activities are unknown and may be of global consequence. Biomass burning has a direct influence on the atmospheric enviroment, decreasing evapotranspiration, increasing concentrations of several greenhouse gases and large aerosols, and influencing atmospheric chemistry (Prins et al., 1992). Aerosol and gases produced by biomass burning also affect each other. Taking Ozone as an example; some researches found that the impact of aerosols on photolysis alone is to increase troposphere Ozone by 0.63 Dobson units (DUs) (Varotsos and Zellner, 2010). Small particulates have direct and indirect radiative effects on the climate and can affect human health when they are inhaled, causing respiratory problems. Biomass burning also disturbs land-based ecosystems (Ichoku, 2008). Scholes and Andreae (2000) have estimated that approximately $9200 \mathrm{Tg} \pm 50 \%$ (dry weight) of terrestrial vegetation is combusted each year.

The different possible sources, types and efficiency levels of biomass burning give this phenomenon a complex chemical composition, making assessments using a single data source nearly impossible. The spatial and temporal distribution of biomass burning also varies, and the chemical composition and physical properties of biomass burning - for example, its size distribution and optical properties - vary during transport due to chemical and physical transformation processes and deposition. All of the above makes estimating the effects of biomass burning quite difficult. However, assessing the effect of biomass burning is very important for research groups and communities interested in climate, atmospheric emissions, carbon cycling and pollution (Tansey et al., 2008). Many biomass burning measurement campaigns have been carried out in recent years (Lee et al., 2005), and a large volume of ground-based data has been collected. However, these campaigns and data have been focused on local effects - for example, researching the influence of the phenomenon on mega-cities or nature reserves (Field et al., 2009; Kundu et al., 2010).

Many studies show that remote sensing is the most practical means of measuring energy release from large-scale open-air biomass burning (Ricardo et al., 1995; PalaciosOrueta et al., 2004; Lee et al., 2005; Bradley and Millington, 2006) because satellite observations may detect unknown global or regional patterns, daily variations and seasonality that are not reproduced by models (Hoelzemann et al., 2009). Initiatives such as the ESA's Climate Change Initiative (CCI) and Global Burnt Area 2000 Project (GBA2000) attempt to evaluate burnt areas using different sensors. Integrating available data from multiple sources creates a broader picture of aerosol characteristics and transport than is obtainable using satellite data products alone (Liu et al., 2009). Multisource information is necessary to increase our understanding of the relationship between biomass burning episodes and their effects. The integration of remote sensing data and surface observations can provide information on different spatial and temporal scales and is suitable for use in both local and global research. The satellite data can provide largescale coverage at daily intervals, whereas ground-based data can provide local data with high temporal resolution.

It has been shown that in areas of low precipitation and in regions with high-temperature dry periods, biomass consumption is greater than in more humid climates (PalaciosOrueta et al., 2005). It is reported that drought, high temperatures and some other human factors have led to Russia's worst wildfires in modern history. Several hundreds of people have lost their lives, thousands of homes and dachas have been destroyed, and the associated direct losses up until 15 August 2010 have been estimated at more than 15 billion. A map of global fire activity for 2010 as detected using the MODIS sensor is shown in Fig. 1 (http://maps. geog.umd.edu/firms/kml.htm\#russia_asia). This illustration clearly shows the significant influence of biomass burning during August 2010 compared with other months. It is necessary to evaluate the impact effect of the Russian wildfires on local areas and neighbouring countries. Figure 1 shows that the fires in west Russia are much fiercer than those in Central Russia. This paper will focus on the fires near Moscow.

The key question is which information should be used for analysis and how to integrate the source information. This paper focuses on transport and effects on larger areas using a combination of satellite remote sensing, ground-based observations and modelling. In this study, satellite data and ground-based measurement data were analysed to estimate the smoke aerosol's impact on the local and global atmospheric enviroment. The main emission sources of trace gases $\left(\mathrm{NO}_{2}, \mathrm{SO}_{2}\right)$ are fossil fuel combustion, soil release, biomass burning and lightning (Seinfeld and Pandis, 1998). 

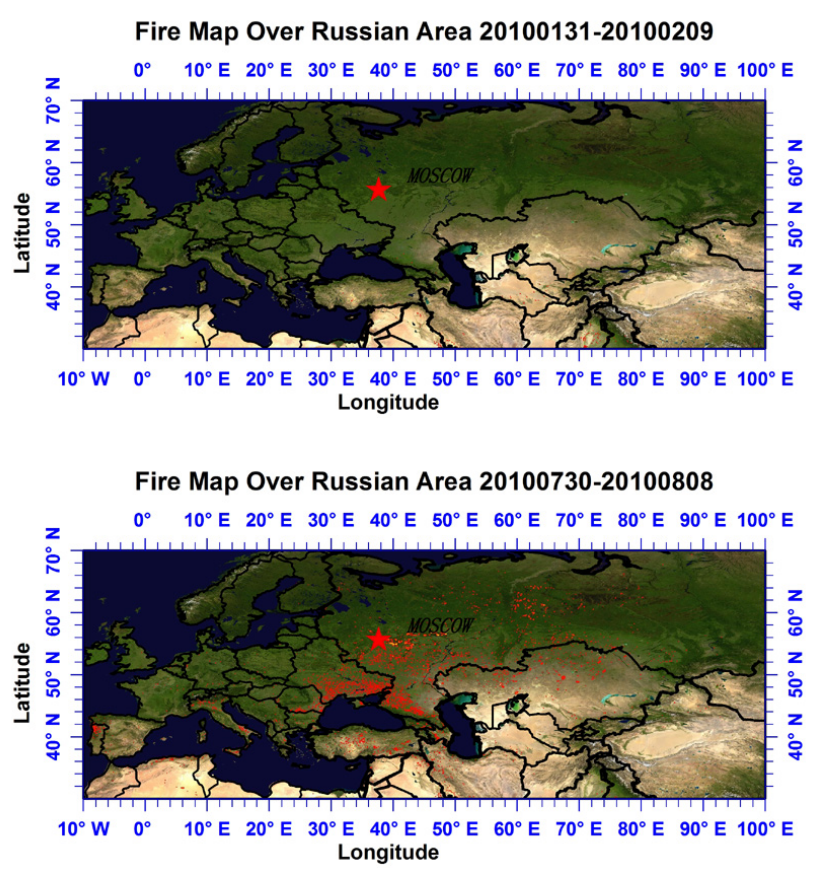
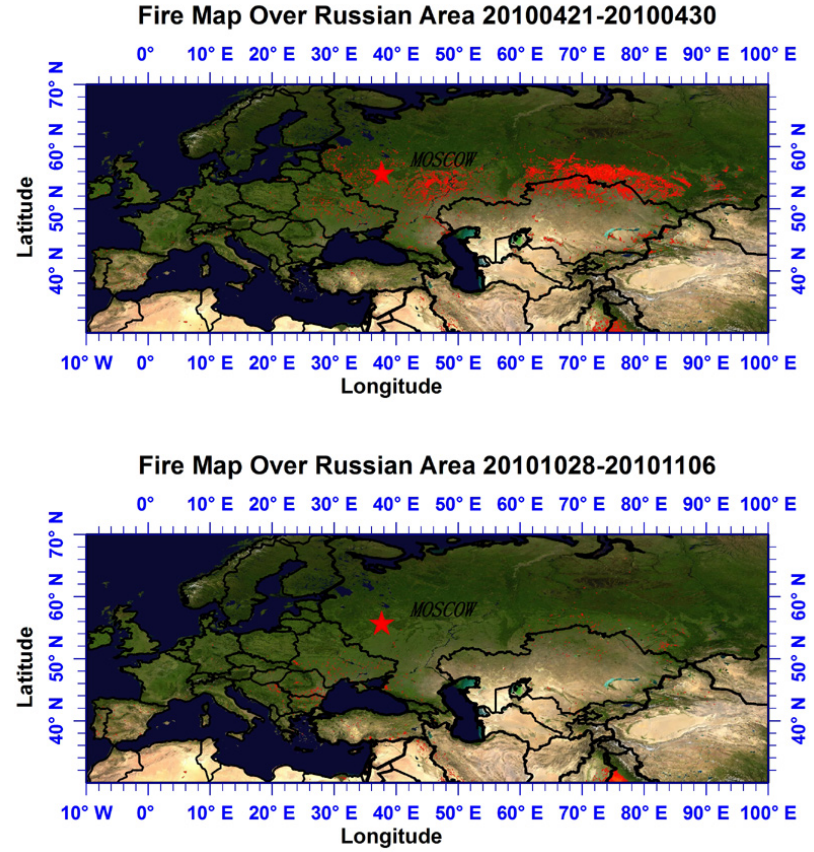

Fig. 1. 10-day Fire map over Russian area in short periods in different seasons (http://maps.geog.umd.edu/firms/kml.htm\#russia_asia).

Although biomass burning is indeed one of the sources of trace gases, anthropogenic activities are responsible for most of the emissions (Beirle et al., 2003; van der A et al., 2008), especially in areas that have experienced rapid economic and social development. Of the anthropogenic emissions, most are from the rapidly increasing number of motor vehicles, power plants and other factories. We have used the variety of trace gases during the Russian wildfires as an indicator of the diminished importance of the anthropogenic contribution. The effect of biomass burning on the amount of $\mathrm{CO}_{2}$ is very obvious because the plume caused by biomass burning contains significant amounts of $\mathrm{CO}$ and $\mathrm{CO}_{2}$; thus, $\mathrm{CO}_{2}$ has been chosen as another indicator of the plume in this paper. There is no doubt that AOD and $\mathrm{PM}_{2.5}$ are the most important parameters of the analysis of biomass burning. However, the influence of the Russian wildfires remains largely unknown because of the lack of source information; many atmospheric parameters (such as AOD data) cannot be retrieved in middle or high latitudes. NASA data seldom include values above $60^{\circ}$. Thus, this paper also proposes some new retrieval methods.

\section{Methods}

\subsection{AOD retrieval algorithm}

The suite of MODIS Dark Dense Vegetation algorithms (DDV) was originally formulated by Kaufman et al. (1997) over land and by Tanre et al. (1997) over water and has been continuously evaluated for self-consistency and comparability to other datasets including AERONET (Remer et al., 2005). The latest version provided by Levy et al. (2007) has significantly evolved from earlier versions and was used to produce MODIS collection 5 which is used in this paper. The level of uncertainty is approximately as $\Delta \tau= \pm 0.015 \pm 0.15 \tau$; here, $\tau$ is the AOD of the total column in atmosphere. Responding to the limitations of the DDV algorithm, Hsu et al. (2004) proposed the use of a new approach (Deep Blue) to determine aerosol properties in bright-reflectance source regions. Good agreements (i.e., relative error within $30 \%$ ) have been obtained between results from the Deep Blue algorithm and ground-based AERONET sun/sky radiometer measurements. However, the AOD results for high latitudes (those larger than 60 degrees) derived using both the DDV and Deep Blue approaches are limited.

The most frequently used approximate radiative transfer equations substitute an exact integrodifferential equation for radiant intensity with common differential equations for upward and incident radiation flux. The general solution to this problem was presented by Kontratyev (1969). We can find the relation between the ground surface reflectance $A^{\prime}$ and apparent reflectance (reflectance on the top of atmosphere) $A$, as proposed by Xue and Craknell (1995), as follows:

$A=\frac{\left(2 A^{\prime}-\sec \theta\right)+\sec \theta\left(1-A^{\prime}\right) e^{(\sec \theta-2) \varepsilon \tau_{0}}}{\left(2 A^{\prime}-\sec \theta\right)+2\left(1-A^{\prime}\right) e^{(\sec \theta-2) \varepsilon \tau_{0}}}$

Where $\varepsilon$ is the backscattering coefficient and $\tau_{0}$ is the atmospheric optical depth, which consists of two parts: the molecular Rayleigh scattering and $\left(\tau_{\mathrm{M}}\right)$ the scattering of the 
aerosol particles $\left(\tau_{\mathrm{A}}\right)$. The variation of the optical depths due to aerosol and molecular scattering with wavelength can be expressed as follows:

$\tau_{\mathrm{A}}=\beta \lambda^{-\alpha}$

$\tau_{\mathrm{M}}=0.00879 \lambda^{-4.09}$

where $\beta$ is Angström turbidity coefficient, $\alpha$ is the wavelength exponent, and $\lambda$ is the wavelength.

Flowerdew and Haigh (1995) proposed that the surface reflectance be approximated by the variation in the wavelength and the variation in the geometry. Under this assumption, the ratio of the two views' surface reflectance can be expressed as follows:

$K_{\lambda_{\mathrm{i}}}=\frac{A_{1, \lambda_{\mathrm{i}}}}{A_{2, \lambda_{\mathrm{i}}}}$

In this study we used data from MODIS on the Terra and Aqua satellites, providing different views, and thus $A_{1, \lambda_{\mathrm{i}}}$ stands for the surface reflectance when TERRA includes the study area and $A_{2, \lambda_{\mathrm{i}}}$ is the surface reflectance when the AQUA data includes it.

Following Eqs. (1) to (4), we assume that for two MODIS observations within the relatively short time between the overpasses of TERRA and AQUA, the ground surface bidirectional reflectance properties and aerosol types and properties $(\alpha)$ do not change. Three visible bands $(0.47 \mu \mathrm{m}, 0.55 \mu \mathrm{m}$ and $0.66 \mu \mathrm{m}$ ) of MODIS were used to retrieve the AOD data. The method of synergetic retrieval of aerosol properties from MODIS data (SRAP-MODIS) has been described in detail by Tang et al. (2005) and Xue et al. (2009). This has proved to be an effective method (Mei et al., 2012), even for highlatitude areas.

The integration of the three methods (DDV, Deep Blue and SRAP-MODIS) above can produce AOD data with greater accuracy and coverage. An integrated AOD product was produced using Optimal Smoothing (OS) to help account for the uncertainty inherent in the model selection process (something that traditional statistical analysis often neglects) as follows:

Suppose that we combine a forward estimate $\hat{x}_{\mathrm{f}}$ of the state and a backward estimate $\hat{x}_{\mathrm{b}}$ of the state to obtain a smoothed estimate of $x$ as follows:

$\hat{x}=K_{\mathrm{f}} \hat{x}_{\mathrm{f}}+K_{\mathrm{b}} \hat{x}_{\mathrm{b}}$

where $K_{\mathrm{f}}$ and $K_{\mathrm{b}}$ are constant matrix coefficients to be determined. Assume that $\hat{x}_{\mathrm{f}}$ and $\hat{x}_{\mathrm{b}}$ are both unbiased. Therefore, if $\hat{x}$ is to be unbiased, we require

$$
\begin{aligned}
& K_{\mathrm{f}}+K_{\mathrm{b}}=I \\
& E\left[\hat{x}_{\mathrm{f}}\right]=E\left[\hat{x}_{\mathrm{b}}\right]=x
\end{aligned}
$$

We define

$$
E\left[\left(\hat{x}-\hat{x}_{\mathrm{f}}\right)^{2}\right]=\hat{\sigma}_{\mathrm{f}}^{2}
$$

$$
\begin{aligned}
& E\left[\left(\hat{x}-\hat{x}_{\mathrm{b}}\right)^{2}\right]=\hat{\sigma}_{\mathrm{b}}^{2} \\
& \hat{x}=K_{\mathrm{f}} \hat{x}_{\mathrm{f}}+\left(I-K_{\mathrm{f}}\right) \hat{x}_{\mathrm{b}}
\end{aligned}
$$

If $E\left[(x-\hat{x})^{2}\right]$ yields the minimal value, then $\hat{x}$ is the best integrated value. This means that

$$
\frac{\partial E\left[(x-\hat{x})^{2}\right]}{\partial x}=0
$$

We can easily find that

$K_{\mathrm{f}}=\frac{\hat{\sigma}_{\mathrm{f}}^{2}}{\hat{\sigma}_{\mathrm{f}}^{2}+\hat{\sigma}_{\mathrm{b}}^{2}}, K_{\mathrm{b}}=\frac{\hat{\sigma}_{\mathrm{b}}^{2}}{\hat{\sigma}_{\mathrm{f}}^{2}+\hat{\sigma}_{\mathrm{b}}^{2}}$.

If there are three AOD products, we can obtain the integration values as follows:

$$
\tau_{\text {integration }}=\operatorname{OS}\left(\tau_{\text {SYNTAM }}, \Delta_{\text {SYNTAM }}, \tau_{\text {DDV }}, \Delta_{\text {DDV }}, \tau_{\text {DeepBlue }}, \Delta_{\text {DeepBlue }}\right)
$$

where $\Delta_{\text {SYNTAM }}$ is the deviation of SRAP-MODIS, $\Delta_{\text {DDV }}$ is the deviation of DDV and $\Delta_{\text {DeepBlue }}$ is the deviation of Deep Blue.

\section{$2.2 \quad \mathrm{PM}_{2.5}$ retrieval}

In situ measurements can provide us with the concentration of $\mathrm{PM}_{2.5}$. However, these measurements do not describe the spatial and temporal variation in $\mathrm{PM}_{2.5}$ or their sources and transport on a regional or global scale. The most common and effective approach is to determine empirical relationships between satellite retrieved AOD and local measurements of $\mathrm{PM}_{2.5}$. Liu et al. (2004) developed a simple but effective way to correct for spatial and seasonal variation in these factors by applying local scaling factors from a global atmospheric chemistry model to AOD retrieval using the Multiangle Imaging SpectroRadiometer (MISR) (van Donkelaar et al., 2006).

Estimated $\mathrm{PM}_{2.5}=\frac{\text { Model surface aerosol concentration }}{\text { Model AOD }} \times$ Retrieved AOD

Chemical transport models, which calculate the fourdimensional distribution of atmospheric aerosol mass, can accurately relate AOD to ground-level $\mathrm{PM}_{2.5}$, allowing estimates in locations without nearby ground-based observations (van Donkelaar et al., 2006, 2010). We can use the GEOSChem chemical transport model (http://acmg.seas.harvard. edu/geos/) to relate AOD to ground-level $\mathrm{PM}_{2.5}$ concentrations. GEOS-Chem is a global 3-D chemical transport CTM model for atmospheric composition. It principally uses meteorological input from the Goddard Earth Observing System (GEOS) of the NASA Global Modelling and Assimilation Office but can also use other meteorological inputs. Evaluations of GEOS-Chem aerosol simulations based on surface and aircraft observations over the USA have been 
previously reported for $\mathrm{OC}, \mathrm{BC}$, SNA, dust, $\mathrm{PM}_{2.5}$, visibility, AERONET AOD and sea salt (Drury et al., 2010). van Donkelaar (2006) proposed the following equation as a means of converting AOD to PM using GEOS-Chem. This has proven to be a high-accuracy method.

$$
M_{2.5, d, \Delta z}=\left[\frac{4}{3}\left(\frac{r_{2.5, d, \Delta z, \mathrm{eff}}}{r_{2.5, \Delta z, \mathrm{eff}}}\right)^{3}\left(\frac{\rho_{2.5, d, \Delta z} r_{2.5, d, \Delta z, \mathrm{eff}} f_{2.5, \Delta z}}{Q_{2.5, e, \Delta z} \Delta z}\right)\right] \tau
$$

where the subscript $\mathrm{d}$ indicates dry conditions and the subscript 2.5 denotes aerosols smaller than $2.5 \mu \mathrm{m}$ in diameter, $M_{2.5, \mathrm{~d}, \Delta z}$ is the total fine dry aerosol mass between the sur-

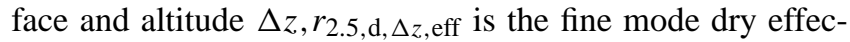
tive radius, and $f_{2.5, \Delta z}$ is the fraction of fine mode AOD below altitude $\Delta z$ to total AOD. AOD-PM 2.5 conversion factors from A. van Donkelaar et al. (personal communication, 2011) were used to relate our AOD retrievals to surface $\mathrm{PM}_{2.5}$.

\subsection{Visibility}

The recent development of satellite meteorology has allowed us to spatially and frequently estimate a number of basic meteorological parameters (Hadjimitsis et al., 2010). Visibility, meteorological visibility (by day) are defined as the greatest distance at which a black object of suitable dimensions (located on the ground) can be seen and recognized when observed against the horizon sky during daylight (World Meteorological Organization, 2003). Understanding the factors that influence atmospheric visibility is important because low visibility can have a disastrous impact on transportation and, in particular, air traffic. In addition, this is a good indicator of air quality. Furthermore, visibility in recreational areas and particularly in national parks is subject to special observance (Baumer, 2007).

There are numerous publications that have addressed the correlation between visibility or visual range and aerosol properties (Elridge, 1986; Retalis et al., 2010). Using the total-column AOD derived from satellite images with the algorithms described in Sect. 2.1, one can calculate visibility as follows (Vermote et al., 1994):

$$
V_{0}=\exp \left(-\log \left(\tau_{550} / 2.7628\right) / 0.79902\right)
$$

\section{Data}

The datasets used in this study include different satellite data and ground-based data. The satellite data include raw data (e.g., MODIS Level 1 data) for determining AOD, $\mathrm{PM}_{2.5}$, visibility and Ångström exponents, and products such as MODIS Level 2 fire products and $\mathrm{CO}_{2}, \mathrm{NO}_{2}$, and $\mathrm{SO}_{2}$ products from OMI. The ground-based data include AERONET sunphotometer data, air-quality monitoring data $\left(\mathrm{PM}_{2.5}\right)$ and meteorological data. These data can be used together to study the long-term characteristics of Russian wildfires in the region.
Table 1. AERONET sites selected for analysis.

\begin{tabular}{llrrr}
\hline AERONET site & Country & Latitude & Longitude & Altitude (m) \\
\hline IASBS & Iran & 36.705167 & 48.507111 & 1805 \\
Issyk-Kul & Kyrgyzstan & 42.622778 & 76.983056 & 1650 \\
Kuopio & Finland & 62.892414 & 27.633606 & 105 \\
Kyiv & Ukraine & 50.363611 & 30.496667 & 200 \\
Lahore & Pakistan & 31.542494 & 74.324753 & 270 \\
Minsk & Belarus & 53.92 & 27.601 & 200 \\
Moscow-MSU-MU & Russia & 55.7 & 37.51 & 192 \\
Tomsk & Russia & 56.477333 & 85.047 & 130 \\
Toravere & Estonia & 58.255 & 26.46 & 70 \\
Yekaterinburg & Russia & 57.038333 & 59.545 & 300 \\
\hline
\end{tabular}

MODIS Level 1 and atmosphere data are available through the LAADS web (http://modis.gsfc.nasa.gov/data/). The MODIS Rapid Response System was developed to provide daily satellite images of the Earth's landmasses in near-real time. The MODIS Rapid Response System Global Fire Maps can be obtained at http://rapidfire.sci.gsfc.nasa.gov/ firemaps/. Each of these fire maps indicates the locations of the fires detected by MODIS via the Terra and Aqua satellites over a 10-day period. The colours depicted range from red (where the fire count is low) to yellow (where the number of fires is large). The compositing periods are referenced using their start and end dates (Julian day).

AERONET provides globally distributed observations of spectral AOD for three data quality levels: Level 1.0 (unscreened), Level 1.5 (cloud-screened), and Level 2.0 (cloudscreened and quality-assured). Ten AERONET sites in the region of interest were used from 31 July 2009 to 15 August 2009 and from 31 July 2010 to 15 August 2010. The cloudscreened Level 1.5 AOD data available from AERONET in different countries were collected during these two years to compare the influence of the Russian wildfires. However, there were no AERONET measurements at the MODIS wavelengths of $0.47,0.55$ and $0.66 \mu \mathrm{m}$. The AOD at $0.5 \mu \mathrm{m}$ was chosen for further analysis. If there was no AOD value at $0.5 \mu \mathrm{m}$, those at $0.675 \mu \mathrm{m}$ were used. Figure 2 shows the AERONET sites in the study area. Table 1 shows the information about latitude, longitude and elevation of selected AERONET sites. Monitoring the turbidity aerosol parameters of background aerosols of natural origin and urban aerosols of industrial origin is of great interest for environmental and climatological studies (Zakey, 2004). The optical properties of smoke that has aged over several days are quite different from those of young smoke, mainly due to significant shifts in the size distribution toward bigger particles (Westphal and Toon, 1991; Reid et al., 1998). To investigate particle size, the Ångström exponent, which is related to the size distribution of the aerosols were calculated based on spectral AOD data.

Atmospheric $\mathrm{CO}_{2}$ concentrations were determined based on the Atmospheric Infrared Sounder (AIRS) 


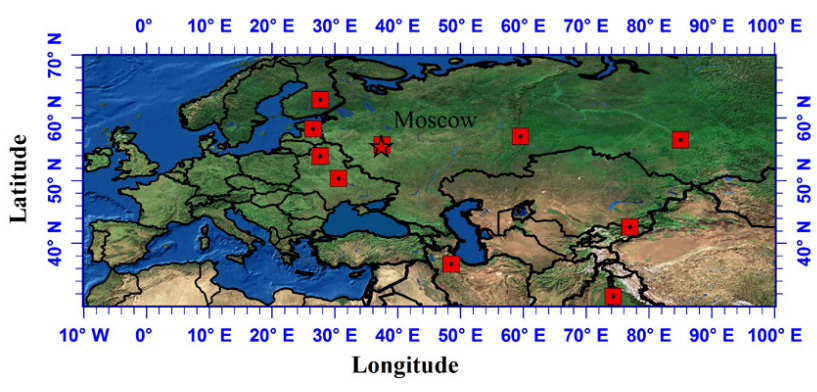

Fig. 2. AERONET sites used in this study (see Table 1 for coordinates and altitude).

data (http://disc.sci.gsfc.nasa.gov/AIRS/data-holdings/ by-data-product/data_products.shtml) from 31 July to 15 August 2010. The resolution of $\mathrm{CO}_{2}$ products is $2.5^{\circ} \times 2^{\circ}$, the same resolution as for GEOS-Chem. Tropospheric $\mathrm{NO}_{2}$ and $\mathrm{SO}_{2}$ datasets from OMI have been widely used to analyse the trends in $\mathrm{NO}_{2}$ and $\mathrm{SO}_{2}$ and their global distribution, to monitor important Atmos. Environ. events and their effects to the ecological environment, economy and society. Data on $\mathrm{NO}_{2}$ (http://disc.sci.gsfc. nasa.gov/Aura/data-holdings/OMI/omno2g_v003.shtml) and $\mathrm{SO}_{2}$ (http://mirador.gsfc.nasa.gov/cgi-bin/mirador/ presentNavigation.pl?tree=project $\backslash \&$ project=OMI) were also collected for analysis. The resolution of the $\mathrm{NO}_{2}$ images is $0.25^{\circ} \times 0.25^{\circ}$ and that of the $\mathrm{SO}_{2}$ images is $0.125^{\circ} \times 0.125^{\circ}$ and the concentrations were re-sampled to a grid of $1.25^{\circ} \times 1.25^{\circ}$. The $\mathrm{CO}_{2}, \mathrm{NO}_{2}$ and $\mathrm{SO}_{2}$ concentrations are expressed in ppm, molec $\mathrm{cm}^{2}$, and D.U. , respectively.

The surface concentration of $\mathrm{PM}_{2.5}$ in Moscow during the biomass episode period was obtained from SEI Mosecomonitoring (http://www.mosecom.ru/) to investigate the impact of smoke aerosol from the Russian wildfires on surface air quality. Meteorological data were collected to analyse the biomass burning episode on local and global scales.

The temporal evolution of the vertical distribution of aerosol must be determined to understand surface and column aerosol properties (Kim et al., 2005). The key information that is not provided by currently operating observational satellites (except CALIOP; and for well-defined plumes MISR) is the altitude of the aerosol layers in the atmosphere. Aerosols particles in the lowest part of the atmosphere are likely to be quickly removed by rain. On the other hand, particles which are transported to higher altitudes are much more likely to travel over long distances and affect air quality in distant countries. CALIPSO can provide this vital missing piece of information (http://www-calipso.larc.nasa. gov/).

The National Centres for Environmental Prediction (NCEP) provide FNL (Final) Operational Global Analysis synoptic data operationally every six hours on $1.0 \times 1.0$ degree grids. This information is derived from the Global
Table 2. EPA air quality index levels and breakpoints for $\mathrm{PM}_{2.5}$.

\begin{tabular}{|c|c|c|}
\hline AQI Category & Index Values & $\mathrm{PM}_{2.5} 24 \mathrm{~h}\left(\mu \mathrm{g} \mathrm{m}^{3}\right)$ \\
\hline Good & $0-50$ & $0.0-15.4$ \\
\hline Moderate & $51-100$ & $15.5-40.4$ \\
\hline Unhealthy for Sensitive Groups & $101-150$ & $40.5-65.4$ \\
\hline Unhealthy & $151-200$ & $65.5-150.4$ \\
\hline Very Unhealthy & $201-300$ & $150.5-250.4$ \\
\hline \multirow{2}{*}{ Hazardous } & $301-400$ & $250.5-350.4$ \\
\hline & $401-500$ & $350.5-500$ \\
\hline
\end{tabular}

Data Assimilation System (GDAS), which continuously collects observational data from the Global Telecommunications System (GTS) and other sources for many analyses. For this study, synoptic data were collected at http://dss.ucar. edu/datasets/ds083.2/. Temperature and geopotential height at 850 hectopascal $(\mathrm{hPa})$ were used in the analysis.

The HYSPLIT (HYbrid Single-Particle Lagrangian Integrated Trajectory) model is a complete system for computing simple air parcel trajectories and complex dispersion and deposition simulations. HYSPLIT can compute the advection of a single pollutant particle or its trajectory (http: //www.arl.noaa.gov/HYSPLIT_info.php). In this research, HYSPLIT was used to characterise the transport of air-mass over the study area.

\section{Results and analysis}

In this section, we will analyse the effect of Russian wildfires during a period of 16 days in 2010 using both satellite observations and ground measurements. The satellite observations include integrated AOD data obtained using the DDV, Deep Blue and SRAP-MODIS approaches as well as information on $\mathrm{PM}_{2.5}, \mathrm{NO}_{2}, \mathrm{SO}_{2}$, and $\mathrm{CO}_{2}$ from other satellites. We first analyse the satellite observations because satellite observations provide large-scale coverage and near-real time data with two observations per day (using MODIS TERRA and AQUA). Ground measurements, in turn, help us to analyse the local effects of a fire. The $\mathrm{NO}_{2}, \mathrm{SO}_{2}$, and $\mathrm{CO}_{2}$ datasets can be used to separate anthropogenic sources from the effects of wildfires. Table 2 shows the US Environmental Protection Agency (EPA) air quality index levels and breakpoints for $\mathrm{PM}_{2.5}$; the satellite-derived daily $\mathrm{PM}_{2.5}$ is colour segmented according to Table 2 .

\subsection{The synoptic situation over Europe and Asia}

The synoptic situation over Europe and Asia can be determined based on data from 31 July to 15 August 2010. During that time, fire plumes were regularly emitted in the region of Voronezh Oblast; their trajectories can be modelled using 

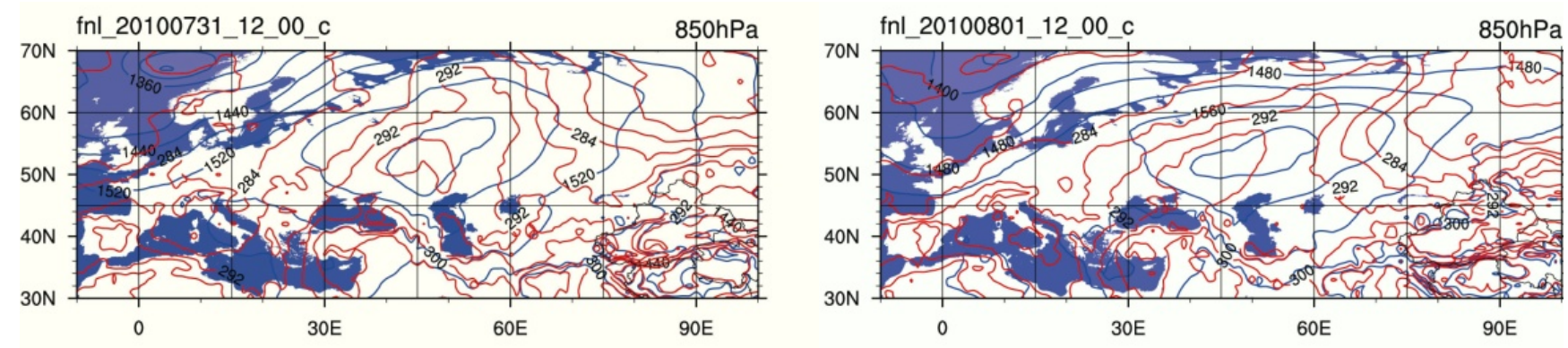

fnl_20100802_12_00_c

$850 \mathrm{hPa}$
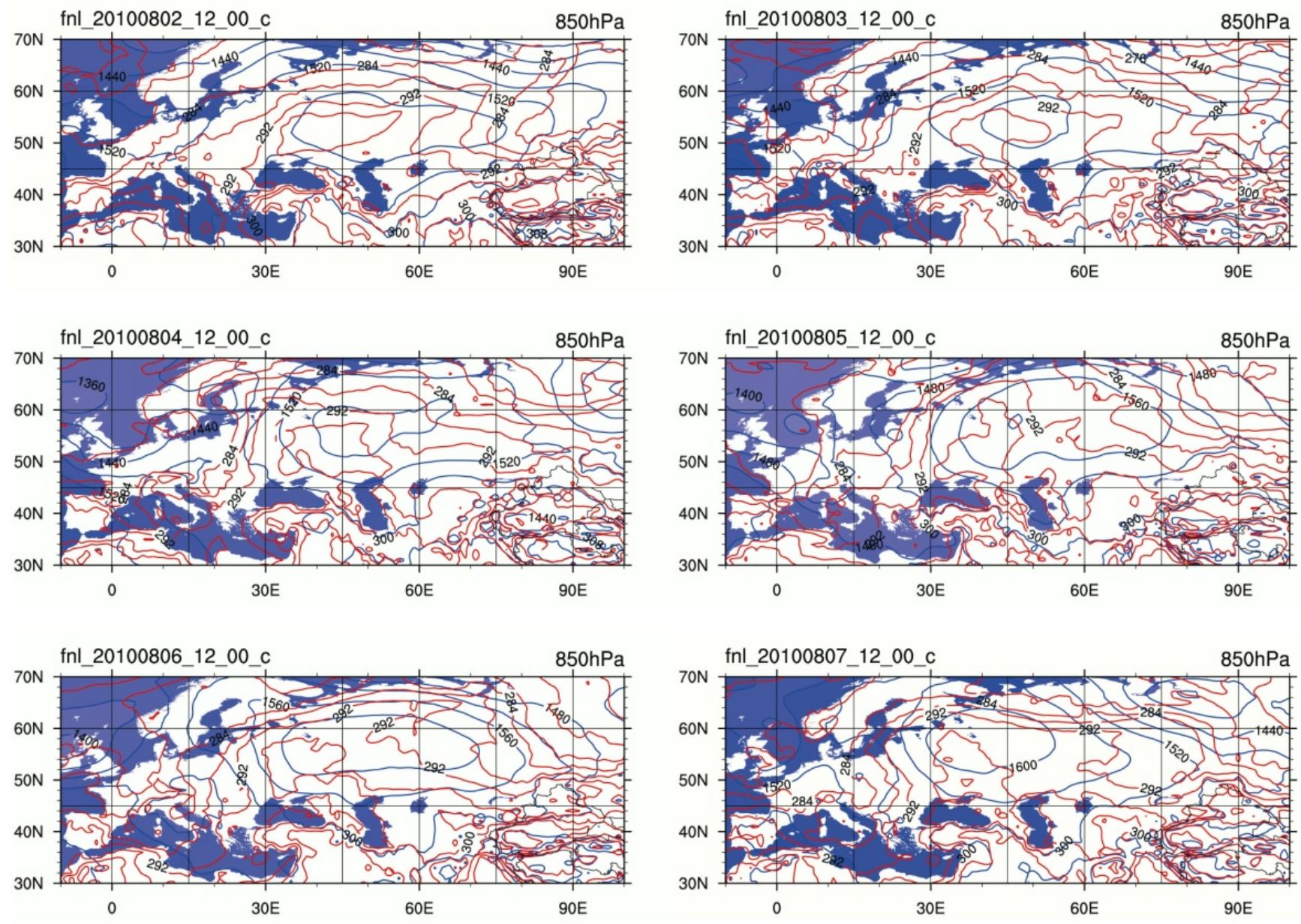

Fig. 3. Synoptic charts for the study area for each day at 12:00 UTC during the period from 31 July to 15 August 2010.

transport models and monitored by satellite imaging as well as ground-based observation. Figure 3 shows the synoptic chart at $850 \mathrm{hPa}$ for the study area for the period from 31 July to 15 August 2010.

A high pressure zone dominated most of Europe and Asia during that period, and there were two low pressure systems. The pressure centre was relatively stable and slowly moved towards the South-East; the high temperature could last for a long time, and this aggravated the fire. The high pressure centre was stable before 9 August 2010, and Moscow was lo- cated at the posterior of the high pressure system. The southern airflow dominated most of the area. The pollution moved slowly northwards, and the westernmost part of Moscow was not affected, whereas some parts of Asia, such as Kyrgyzstan, were affected by the plume. During 10-11 August 2010, the high pressure centre moved eastwards, and Central and Eastern Russia were seriously affected. The precipitation clouds reached some parts of Russia, causing washout of aerosol particles at lower altitudes. However, the high pressure suddenly moved westwards, and the prevailing winds 

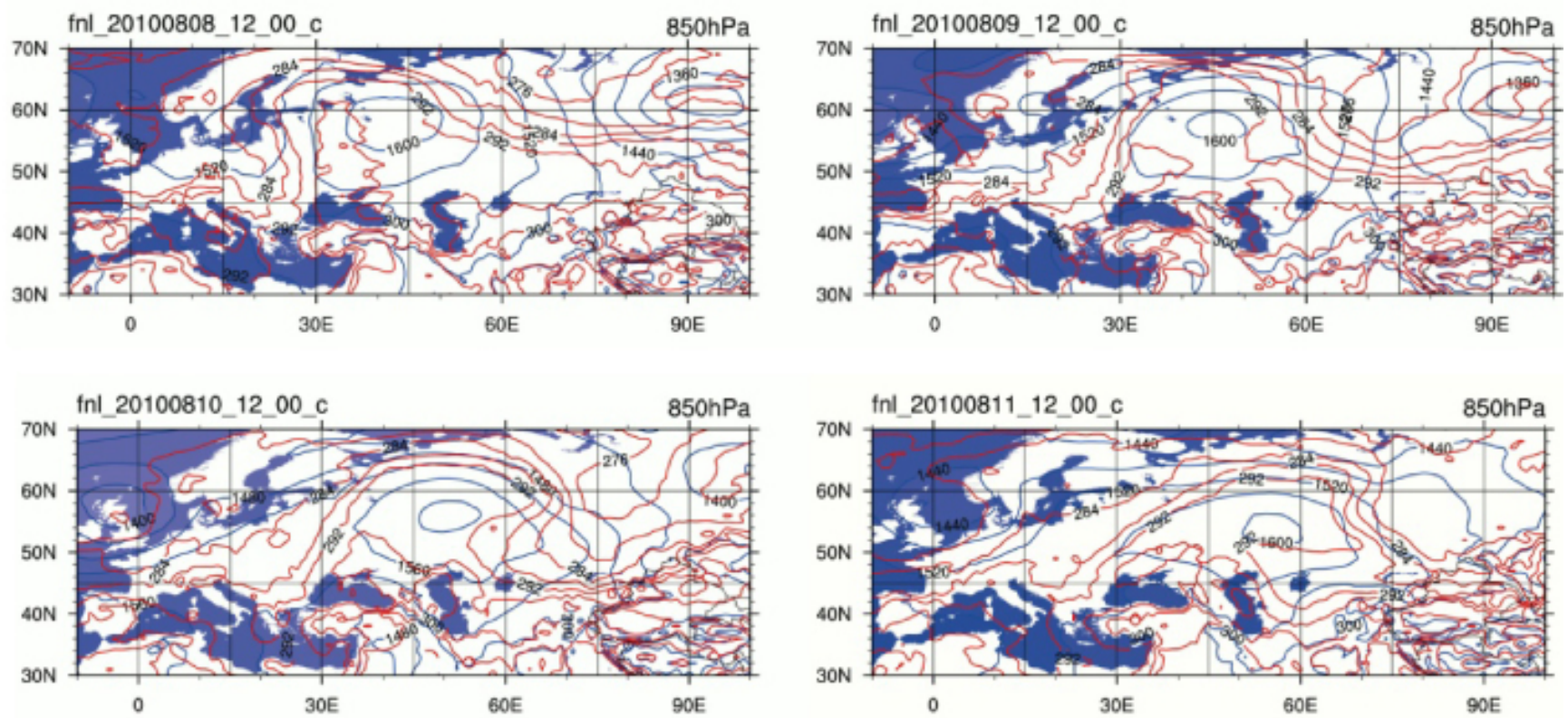

fnl $201008121200 \mathrm{c}$
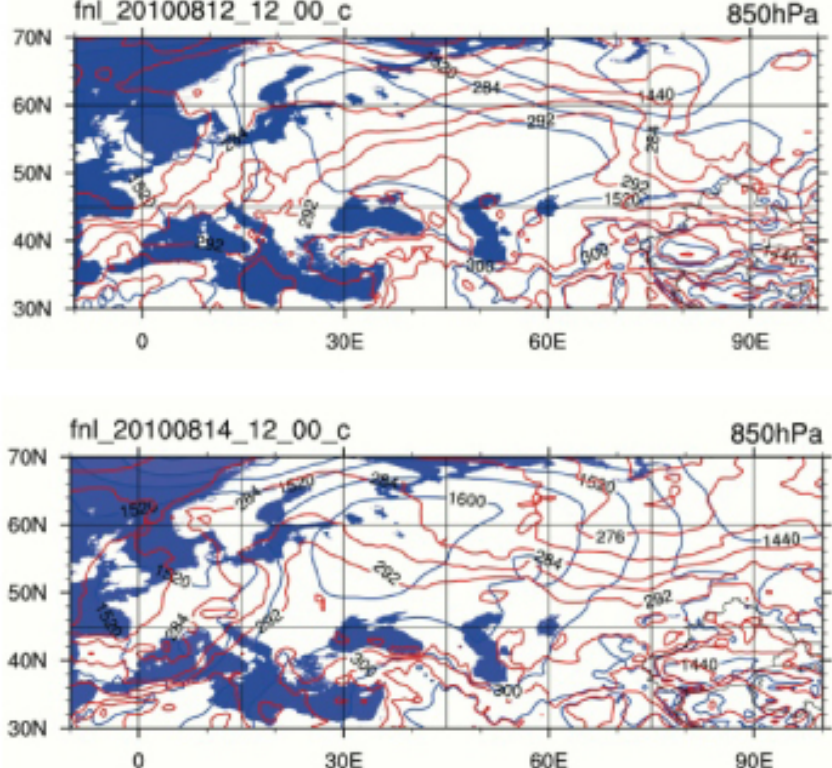
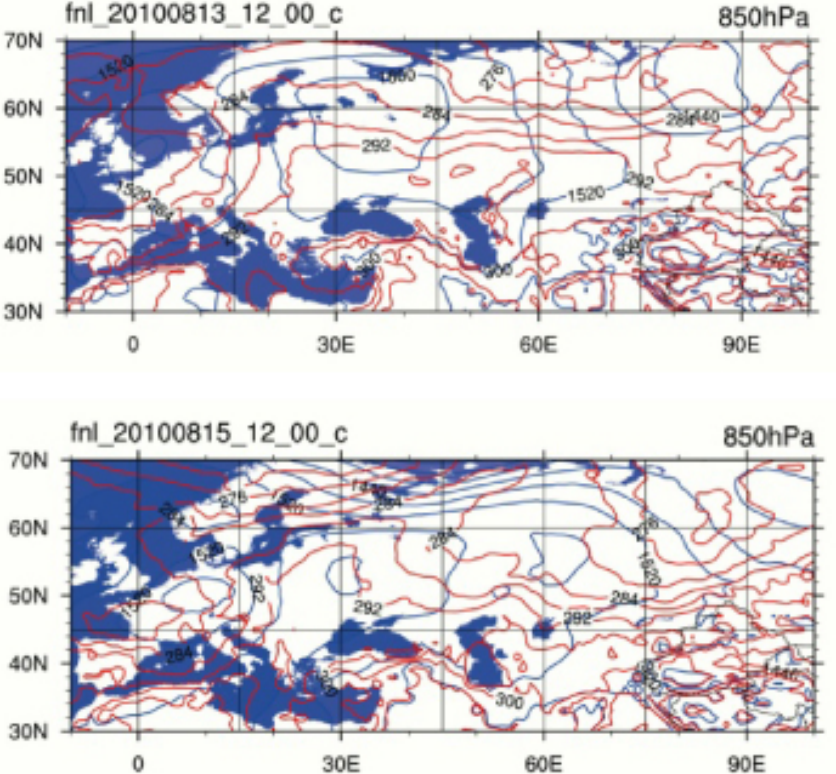

Fig. 3. Continued.

were easterly, carrying the fire plume from that direction after 13 August 2010. Therefore, the plume moved from Western Russia towards Ukraine and toward Central Europe. Based on satellite images, it can be concluded that air masses reached the air space over Ukraine on 14 August 2010.

Data on surface conditions indicate that Finland was affected by the fire plume on 8 August 2010. Figure 3 demonstrates that the surface pressure and wind speeds increased, which facilitated the spread of pollution.

\subsection{Satellite observations}

Figure 4 shows the AOD distribution in the study area during 31 July and 15 August 2010 with a resolution of $10 \times 10 \mathrm{~km}^{2}$. Both Terra and Aqua were used to retrieve AOD data, and the integrated AQUA AOD information is shown. The MODIS AOD data show that this hazy area features relatively high AOD $(>1.0)$, with a maximum exceeding 3.0 and extending as high as 5.0. MODIS AOD measurements suggest that the Russian wildfires affected the aerosol concentrations in the south-eastern part of Moscow on 31 

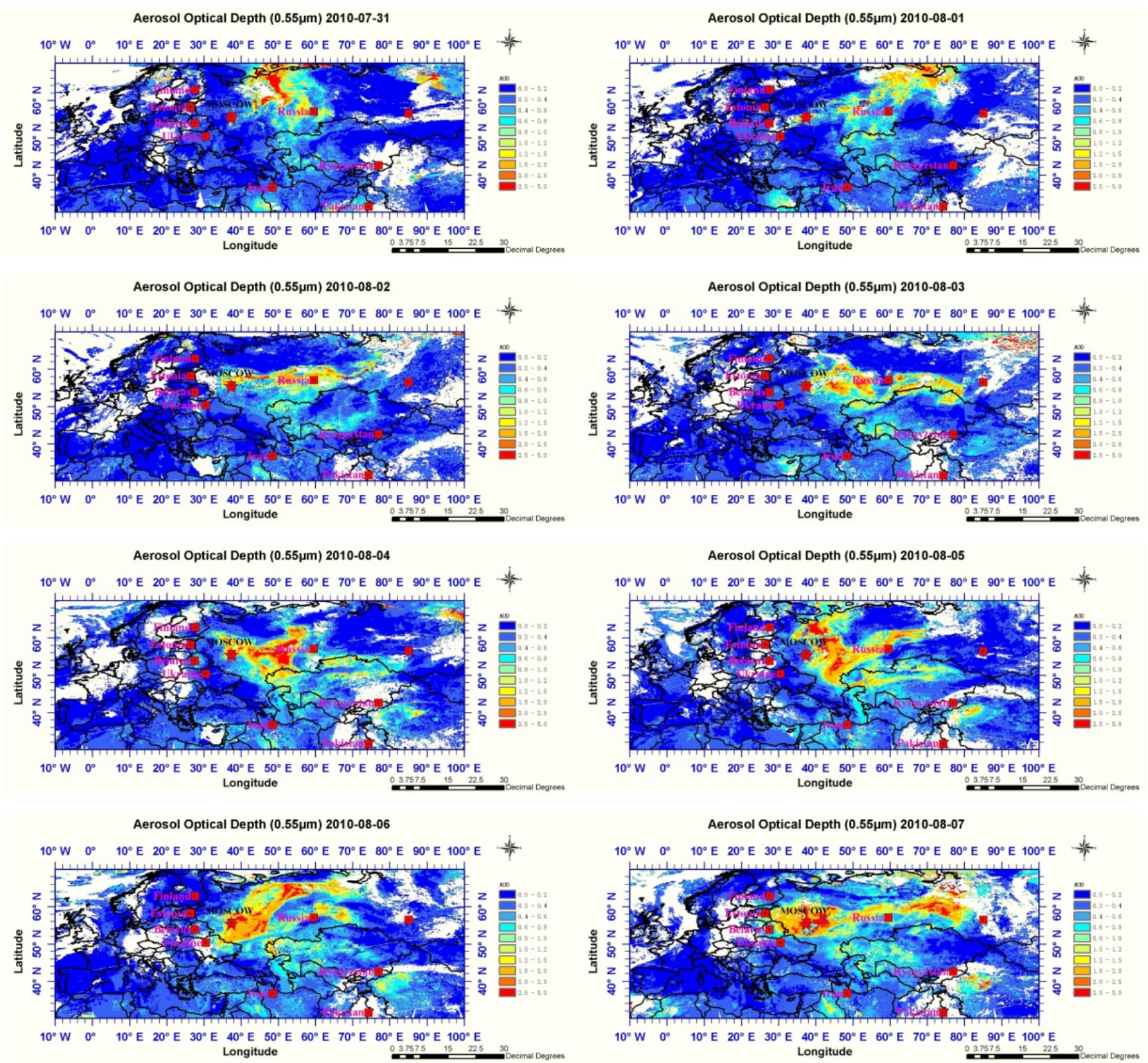

Fig. 4. AOD (at $0.55 \mu \mathrm{m}$ ) distribution over the study area for the period from 31 July to 15 August 2010. The AOD was obtained from integration of the AOD retrieved from three different methods as described in the text.

July; the AOD in the south-eastern part of the Moscow region is about 0.7, whereas the AOD is about 0.4 in the northern part of the region. Figure 5 shows the mean satellitederived daily $\mathrm{PM}_{2.5}$ concentrations in the study region from 31 July to 15 August 2010. The mean satellite-derived $\mathrm{PM}_{2.5}$ concentrations ranged from $15.5-40.4 \mu \mathrm{g} \mathrm{m}^{3}$ in the northern part of Moscow and less than $15.4 \mu \mathrm{g} \mathrm{m}^{3}$ in the west part of Moscow when the smoke had no effect and increased. The mean satellite-derived $\mathrm{PM}_{2.5}$ concentrations were higher in the urban centre at around $50 \mu \mathrm{g} \mathrm{m}^{3}$ due to local emissions. Based on Figs. 4 and 5, we can also see that the plume arrived in Moscow on 1 August 2010 and the fire affected Moscow from 1 to 15 August except for 3 and 5 August. These results may be due to changes in meteorological conditions (including wind speed and direction, atmospheric stability, temperature and precipitation). The largest plumes were seen in Moscow on 6-9 August 2010, with $\mathrm{PM}_{2.5}$ concentrations over $500 \mu \mathrm{g} \mathrm{m}^{3}$. Figure 6 demonstrates that the southwestern wind brought plumes of smoke to all of Moscow and neighbouring countries on 6 August 2010. Because the concentration levels of other anthropogenic substances $\left(\mathrm{SO}_{2} \mathrm{NO}_{2}\right)$ were not elevated at this time, the influence of a 

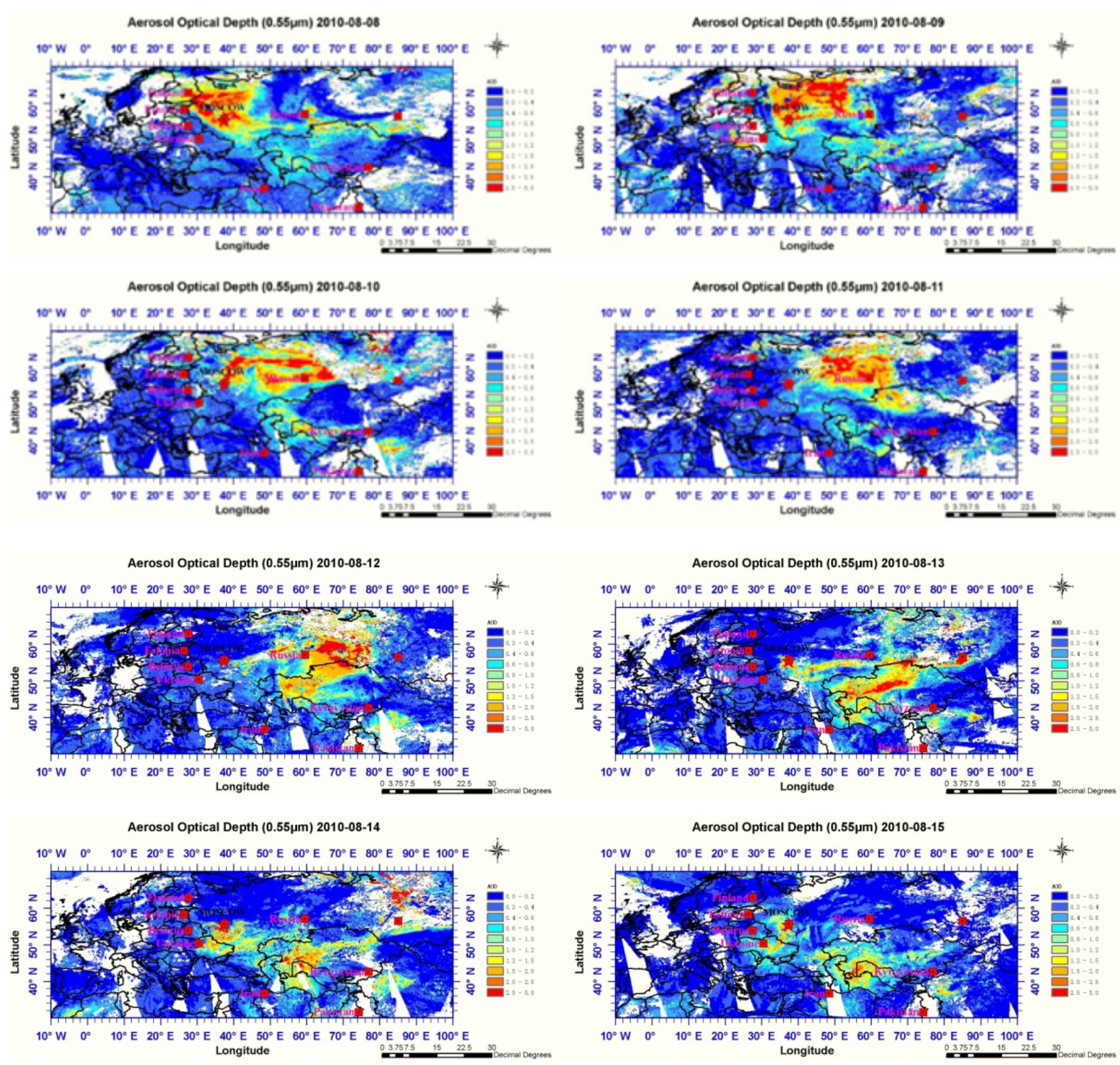

Fig. 4. Continued.

non-anthropogenic component (i.e., the biomass burning) is likely (Witham et al., 2007). The $\mathrm{CO}_{2}$ concentrations shown in Fig. 7 are quite high leading up to the fire event. An interesting finding is that the amount of $\mathrm{SO}_{2}$ increased on 4 and 5 August 2010 and especially on 5 August. One possible reason is that the air quality improved and more anthropogenic activities increased the volume of related compounds. Central Russia was seriously affected by the fire from 31 July to 12 August 2010 and especially during 10-12 August, with AOD values over 2.5 and values for $\mathrm{PM}_{2.5}$ concentration over $300 \mu \mathrm{g} \mathrm{m}^{3}$. The amounts of $\mathrm{SO}_{2}, \mathrm{NO}_{2}$ and $\mathrm{CO}_{2}$ also increased during the period from 10 to 12 August. Figure 4 suggests that although the smoke plumes moved eastward, they did not reach Tomsk, and Eastern Russia was little affected by the fire. This is the case even though the AOD values were slightly higher than normal for several days (such as on 7 August and 10 August). The amounts of $\mathrm{SO}_{2}, \mathrm{NO}_{2}$ and $\mathrm{CO}_{2}$ at a representative point (in Minsk) support this conclusion. Figure 4 shows that the plume may have moved toward the Arctic region, especially from 31 July to 1 August and from 5 to 14 August 2010. 

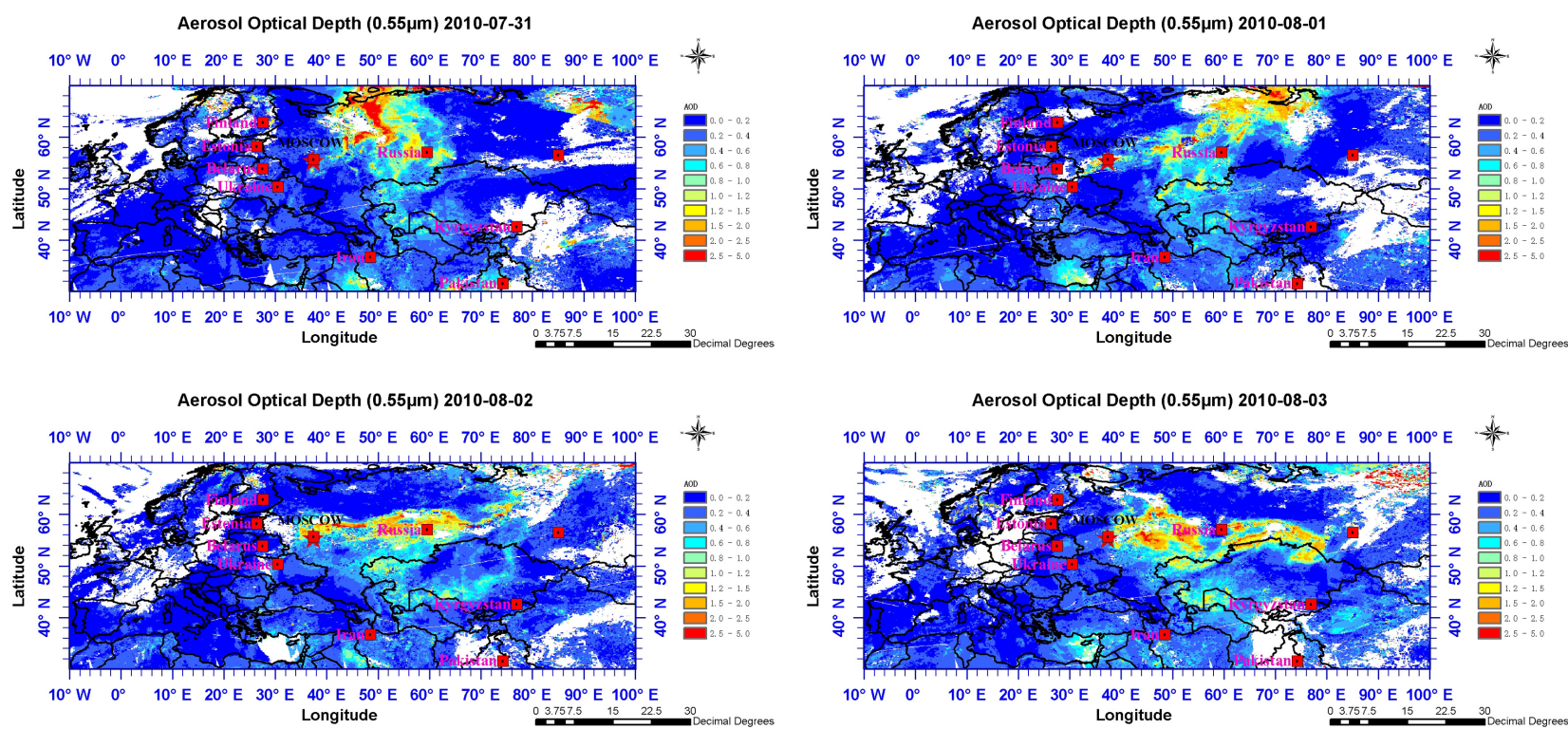

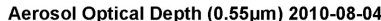
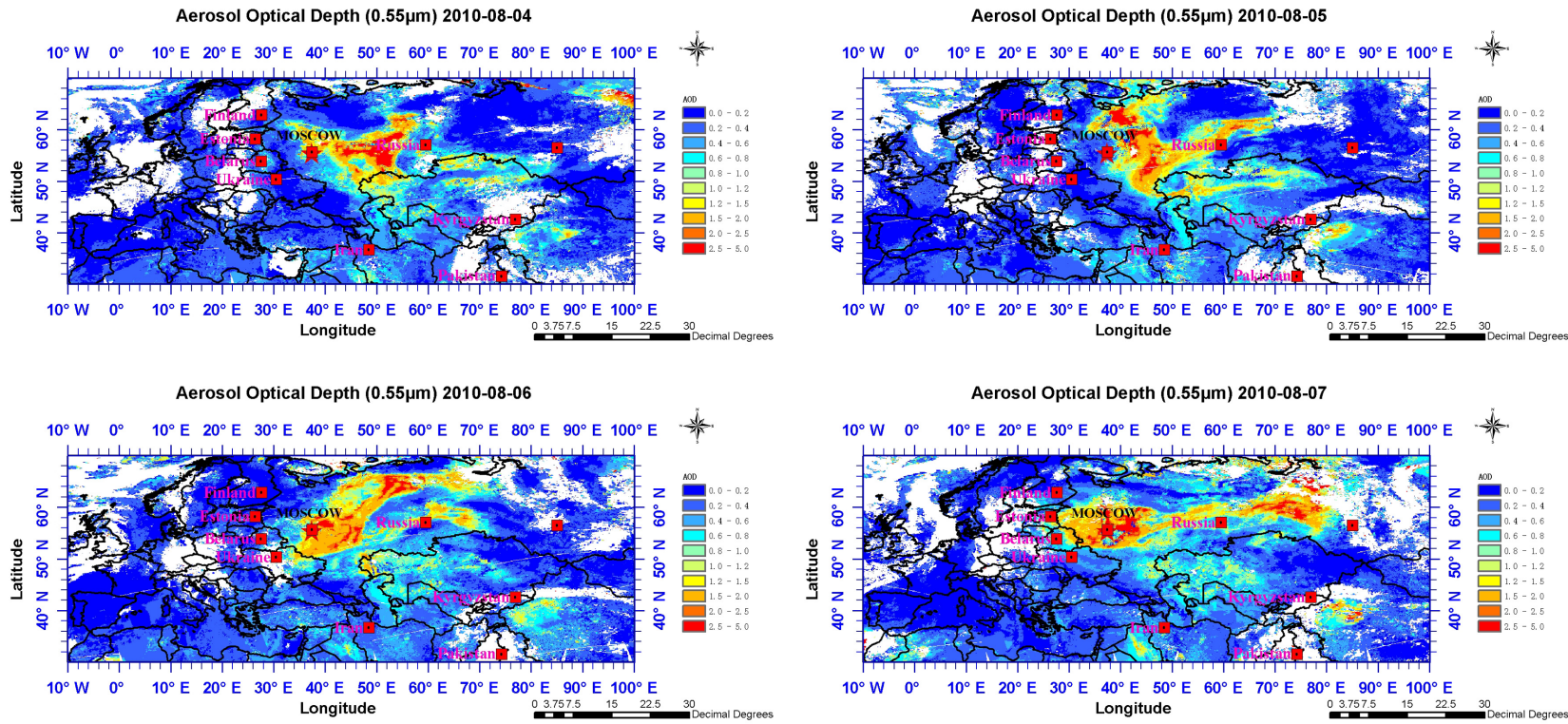

Fig. 5. $\mathrm{PM}_{2.5}$ (in $\mu \mathrm{g} \mathrm{m}^{-3}$ ) distribution over the study area for the period from 31 July to 15 August 2010 . The mean satellite-derived daily $\mathrm{PM}_{2.5}$ concentrations were calculated from the methods as described in the text.

Figures 4 and 5 show that during the study period the AOD in Eastern Europe was less than 0.3, and the $\mathrm{PM}_{2.5}$ concentration less than $30 \mu \mathrm{g} \mathrm{m}^{3}$ in some areas; in Finland, the $\mathrm{PM}_{2.5}$ concentration was less than $15.4 \mu \mathrm{g} \mathrm{m}{ }^{3}$. However, when the wildfire plume moved westward it affected eastern european countries such as Ukraine and Belarus on $6 \mathrm{Au}-$ gust 2010, Estonia on 7 August, and Finland on 8 August (see Fig. 6); the $\mathrm{PM}_{2.5}$ concentrations were 3-5 times the normal values on these days. The meteorological conditions favoured the dilution and spread of aerosol and trace gases from 9 to 14 August 2010, which decreased the values for AOD and $\mathrm{PM}_{2.5}$ concentration. However, the plume reached
Ukraine again on 14 and 15 August 2010, whereas the plume had little effect on other european countries, merely depositing some vestigial particulate matter in the air.

We next analysed the effect of the plume on specific countries from north to south. Finland was first affected by the fire on 8 August 2010, as indicated in Figs. 4 and 5. It was found that the air conditions in the northern part of Finland were much better than those in the southern part because the latter is the most developed economic area in Finland and there are more anthropogenic emissions in the southern part. Taking 7 August as an example, Figs. 4 and 5 show that the AOD and $\mathrm{PM}_{2.5}$ values for the southern part were much higher than 

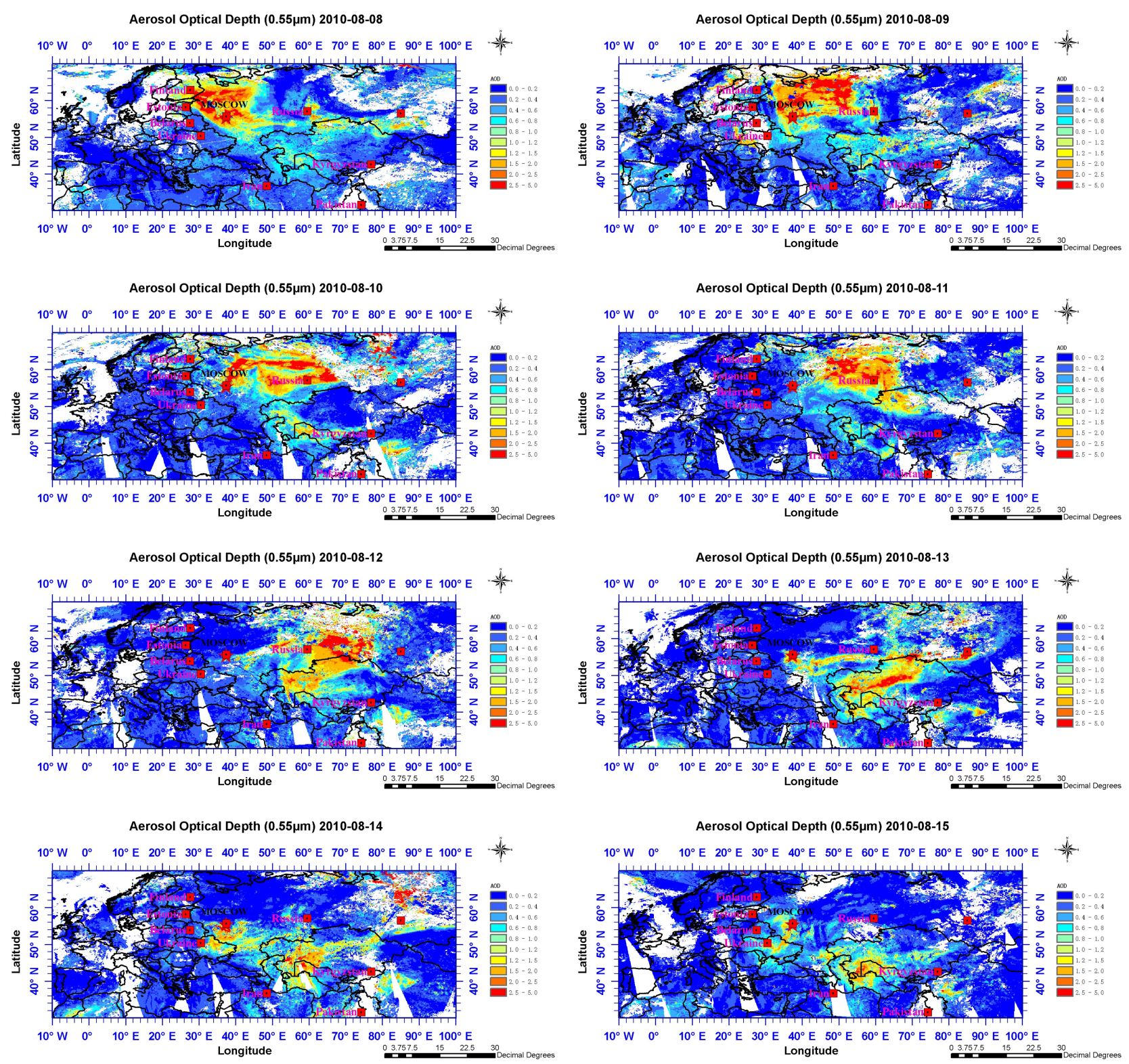

Fig. 5. Continued.

those for the northern part. Figure 7 shows that there was a peak in the concentrations of $\mathrm{NO}_{2}, \mathrm{SO}_{2}$ and $\mathrm{CO}_{2}$, implying that the atmospheric environment of Finland was effected by local emissions as well as by transport from elsewhere. On 8 August, levels of anthropogenic species $\left(\mathrm{SO}_{2}\right.$ and $\left.\mathrm{NO}_{2}\right)$ were not elevated in contrast to the concentration of $\mathrm{CO}_{2}$, indicating that Finland was seriously affected by the plume on 8 August, 2010. $\mathrm{PM}_{2.5}$ concentrations increased to $60 \mu \mathrm{g} \mathrm{m}{ }^{3}$, a level 4 times higher than normal. Estonia was strongly affected by the plume on 7 August, 2010; the AOD increased from 0.3 to over 1.2, and the $\mathrm{PM}_{2.5}$ concentration increased from $20 \mu \mathrm{g} \mathrm{m}^{3}$ to over $100 \mu \mathrm{g} \mathrm{m}^{3}$. Figure 7 shows that an- thropogenic emissions had little effect on AOD and $\mathrm{PM}_{2.5}$ and that the transport of the plume was the dominant influence for the observed increases in concentrations. However, the air quality improved because of the dispersion of particulate matter, and the fire had little effect on the concentrations in Estonia after 7 August 2010. The fire began to affect Belarus on 6 August 2010, and the greatest effect occurred on 7 August 2010. The influence of remaining particles lasted until 15 August 2010; however, the effect was quite small, and there was no effect on 11 and 12 August 2010 on the whole. As shown in Fig. 7, anthropogenic emissions may have also contributed to the increase in AOD and $\mathrm{PM}_{2.5}$ 

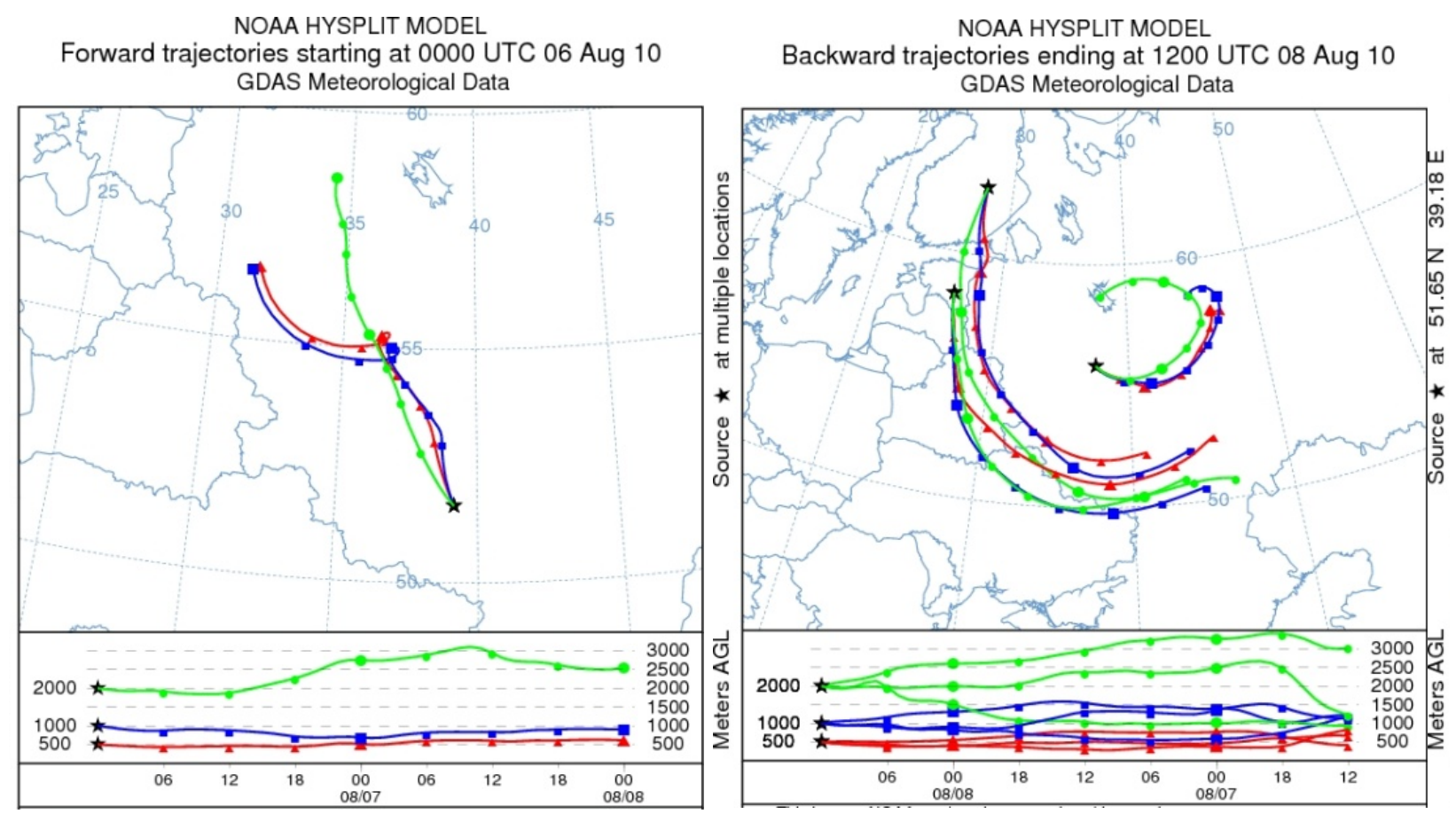

Fig. 6. Air flow trajectories for a $48 \mathrm{~h}$ time interval with $6 \mathrm{~h}$ temporal resolution obtained from the HYSPLIT model. Left: forward trajectories for air masses originating near the Voronezh Oblast starting on 6 August 2010 at 12:00 UTC; Right: backward trajectories of air masses reaching Moscow, Finland and Estonia on 8 August 2010 at 12:00 UTC. The bottom panels show the height of the air mass in meters above ground level.

concentrations, and the effect of anthropogenic emissions was quite unstable. AOD and $\mathrm{PM}_{2.5}$ suddenly increased on 4 and 5 August 2010 due to local emissions. The effect to Ukraine was somewhat unexpected; Figs. 4 and 5 show that the fire began to affect Ukraine on 6 August 2010, but the effect decreased because of meteorological conditions, and there was no overall effect on that country as a whole. Then on 14 and 15 August, 2010, the fire "reached" Ukraine again; AOD levels increased to 1.2 , and $\mathrm{PM}_{2.5}$ concentration increased to over $100 \mu \mathrm{g} \mathrm{m}^{3}$. The amount of $\mathrm{SO}_{2}$ increased at the same time, and $\mathrm{NO}_{2}$ and $\mathrm{CO}_{2}$ fluctuated within a narrow range, implying that anthropogenic emissions may have contributed to the increase in AOD and $\mathrm{PM}_{2.5}$. Overall, however, it can be concluded that the Russian wildfires affected several european countries during a short period of time.

Most Asian countries are developing countries. Figures 4 and 5 show that the $\mathrm{PM}_{2.5}$ concentrations there were much higher than those in european countries. The $\mathrm{PM}_{2.5}$ concentrations mostly ranged from $40-80 \mu \mathrm{g} \mathrm{m}^{3}$ but in some regions even extended as high as $100 \mu \mathrm{g} \mathrm{m}^{3}$. The Russian wildfires had the largest effect on Asia, especially for neighbouring countries. This was mainly due to the atmospheric pressure and wind direction at high latitudes. In Kazakhstan, for example, the effect of the Russian wildfires lasted for a long time and was the most serious from 12 to 13 August 2010, when the AOD values were higher than 2.0 and $\mathrm{PM}_{2.5}$ in- creased to $150 \mu \mathrm{g} \mathrm{m}{ }^{3}$. However, the effect of the wildfires on non-neighbouring countries is illustrated for three countries (Kirghizstan, Iran and Pakistan). Due to cloud cover, the satellite instruments did not have direct visual access to Kirghizstan for several days, but the AOD values for the surrounding pixels suggest approximate values for that country. Figures 4 and 5 show that the fire began to affect Kirghizstan on 10 August 2010 and that the effect lasted until $15 \mathrm{Au}-$ gust 2010. Figure 7 demonstrates that local emissions might have contributed to the increase in AOD and $\mathrm{PM}_{2.5}$ on $13 \mathrm{Au}-$ gust 2010 but that the fire had a strong influence on Kirghizstan during the period 10-14 August 2010, especially in the western part of Kirghizstan, where the $\mathrm{PM}_{2.5}$ concentration values increased to $100 \mu \mathrm{g} \mathrm{m}^{3}$. The fire had little effect on Iran and Pakistan. The distribution of AOD and $\mathrm{PM}_{2.5}$ on 13-15 August 2010 in Iran and on 14 August 2010 in Pakistan indicates that the fire may have affected the local atmospheric enviroment, but Fig. 7 shows that local emissions were also very high. Thus, more data will be needed for further analysis. Overall, the Russian wildfires strongly influenced neighbouring asian countries for a significant period of time, whereas little effect was found for other countries. 


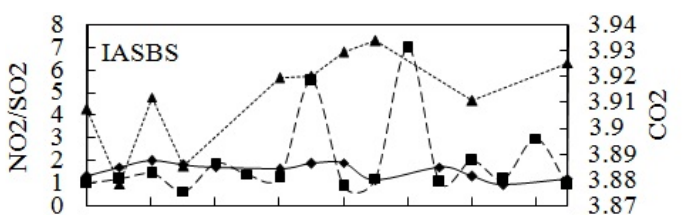

$\begin{array}{llllllll}212 & 214 & 216 & 218 & 220 & 222 & 224 & 226\end{array}$

Julian Day

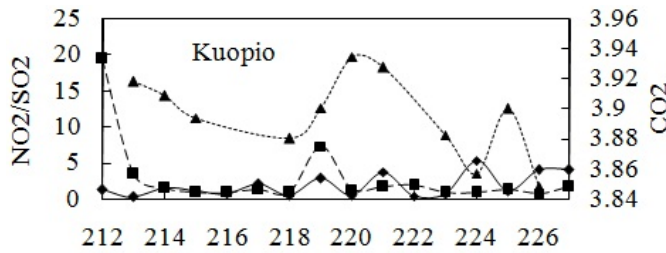

Julian Day

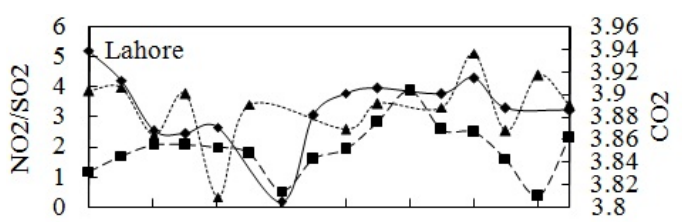

$\begin{array}{llllllll}212 & 214 & 216 & 218 & 220 & 222 & 224 & 226\end{array}$

Julian Day

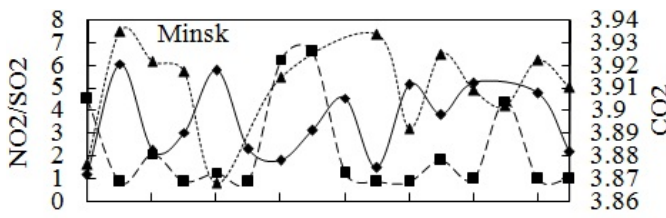

$\begin{array}{llllllll}212 & 214 & 216 & 218 & 220 & 222 & 224 & 226\end{array}$

Julian Day

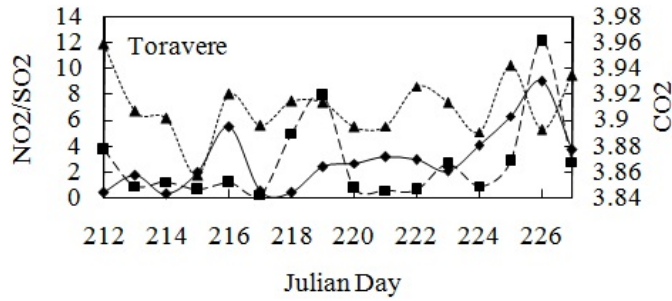

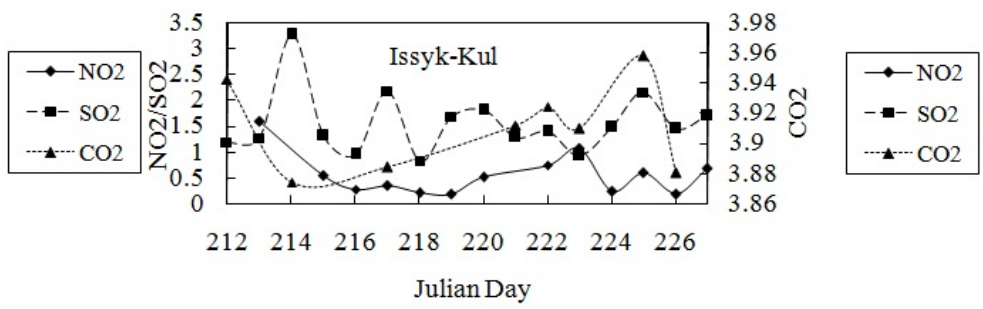
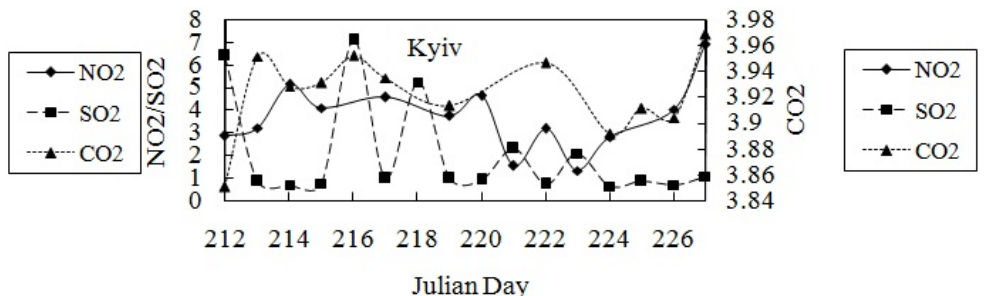

$\begin{array}{llllllll}212 & 214 & 216 & 218 & 220 & 222 & 224 & 226\end{array}$

Julian Day
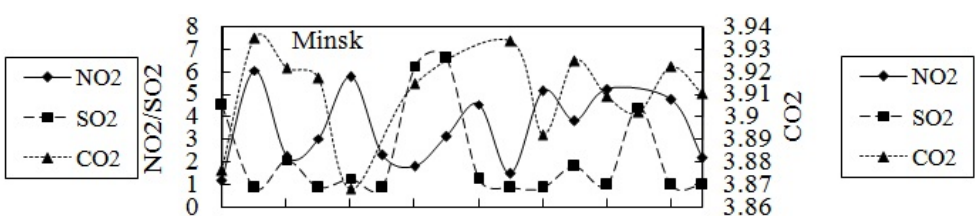

$\begin{array}{llllllll}212 & 214 & 216 & 218 & 220 & 222 & 224 & 226\end{array}$

Julian Day
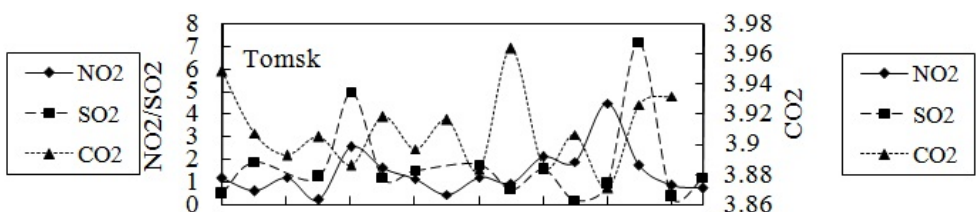

$\begin{array}{llllllll}212 & 214 & 216 & 218 & 220 & 222 & 224 & 226\end{array}$

Julian Day
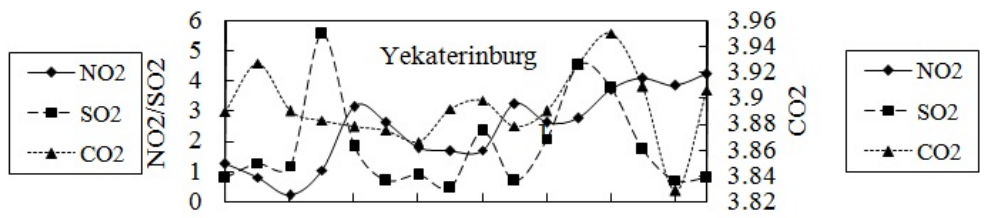

$\begin{array}{llllllll}212 & 214 & 216 & 218 & 220 & 222 & 224 & 226\end{array}$

Julian Day

Fig. 7. Time series of the concentrations of $\mathrm{NO}_{2}, \mathrm{SO}_{2}$ and $\mathrm{CO}_{2}$ in different countries. The $\mathrm{CO}_{2}, \mathrm{NO}_{2}$ and $\mathrm{SO}_{2}$ concentrations are expressed in ppmv (partspermillionbyvolume), molec $\mathrm{cm}^{2}$, and D.U., respectively. To make appropriate comparisons, all $\mathrm{CO}_{2}$ values were divided by 100 , all $\mathrm{NO}_{2}$ were divided by $10^{15}$.

\subsection{Ground measurements}

This section presents an analysis of in situ AOD measurements by the AERONET network in the study area during 2010 in comparison with those for the year 2009. We used data from ten measurement sites shown in Table 1 and Fig. 3, which are located around the biomass burning area, with measurements continuously available. The time series for the Ångström exponents $(440-870 \mathrm{~nm})$ at the ten AERONET sites as a relative measure of fine versus coarse mode contri- butions to total AOD (Reid et al., 1998; Eck et al., 2001). Figure 8 shows continuous measurements for the AOD values and Ångström exponents (440-870 nm) from 31 July to 15 August 2010 at each of the ten AERONET sites except Lahore (because there was no data for the latter city from this period).

Three AERONET sites (Moscow-MSU-MO, Tomsk and Yekaterinburg) located in different areas in Russia (MoscowMSU-MO in Western Russia, Yekaterinburg in the middle Russia and Tomsk in East Russia) were chosen for further 

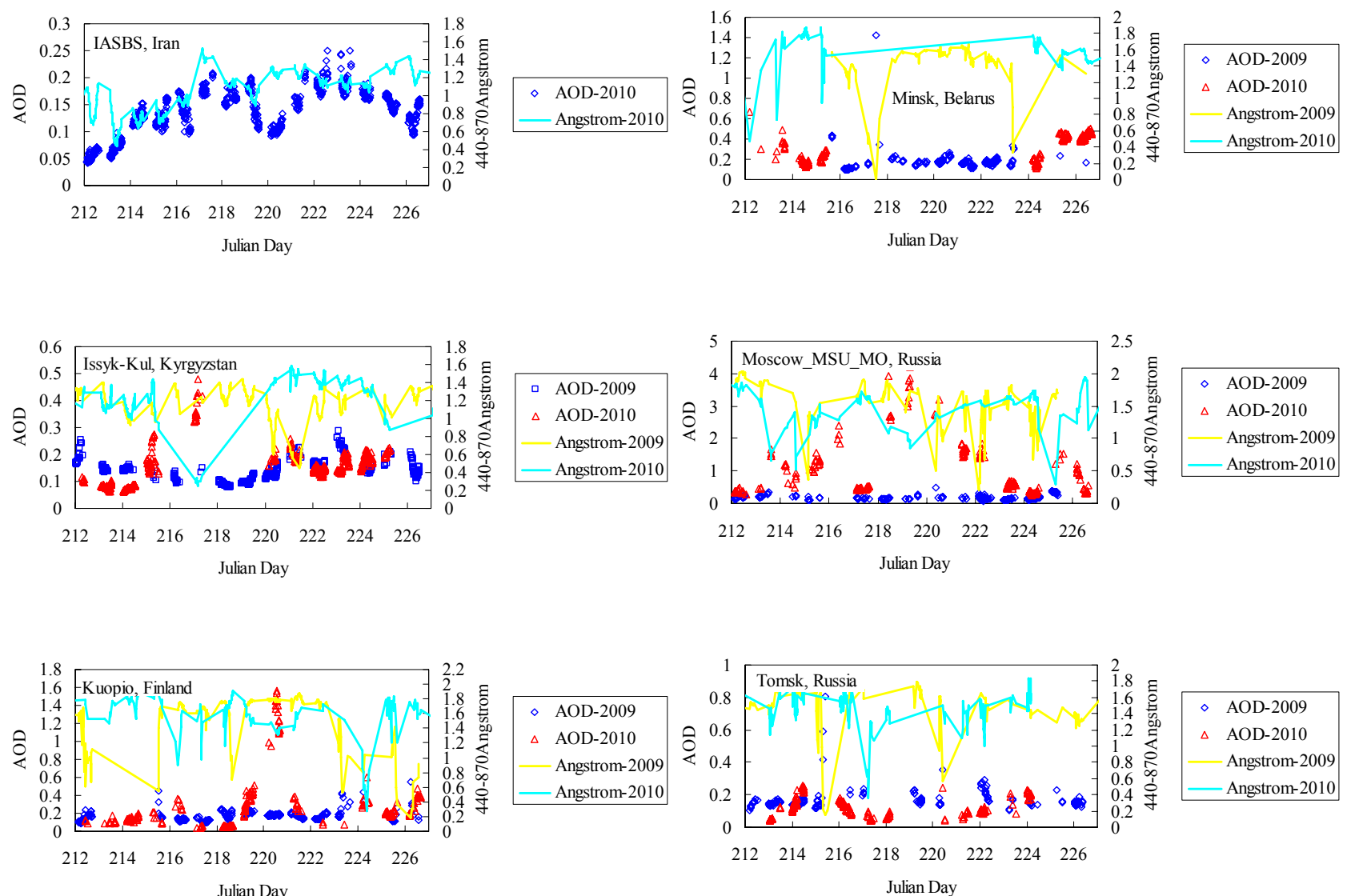

$\begin{array}{llllllll}212 & 214 & 216 & 218 & 220 & 222 & 224 & 226\end{array}$

Julian Day
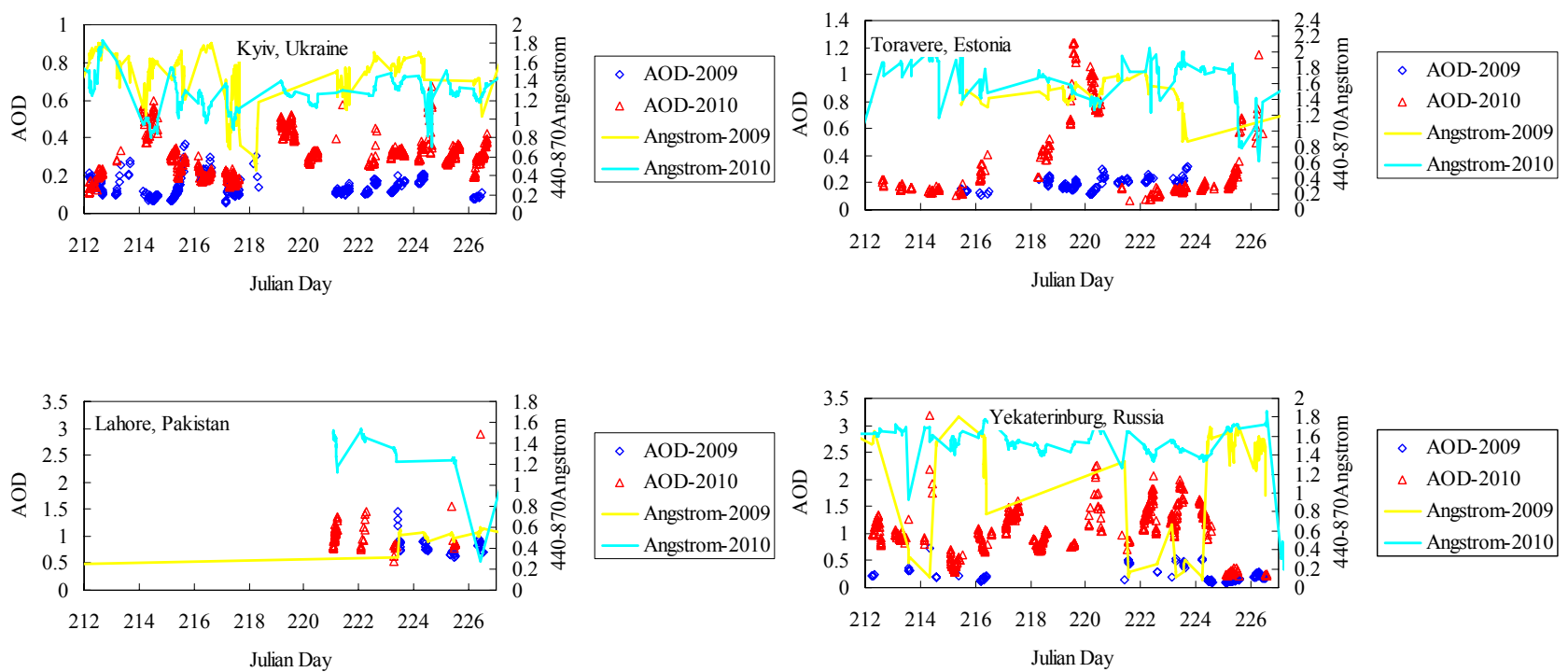

Fig. 8. Time series of aerosol optical depth at $500 \mathrm{~nm}$ and Ångström exponent ( $400-870 \mathrm{~nm}$ ) at different AERONET sites during 16 days in both 2009 and 2010. 


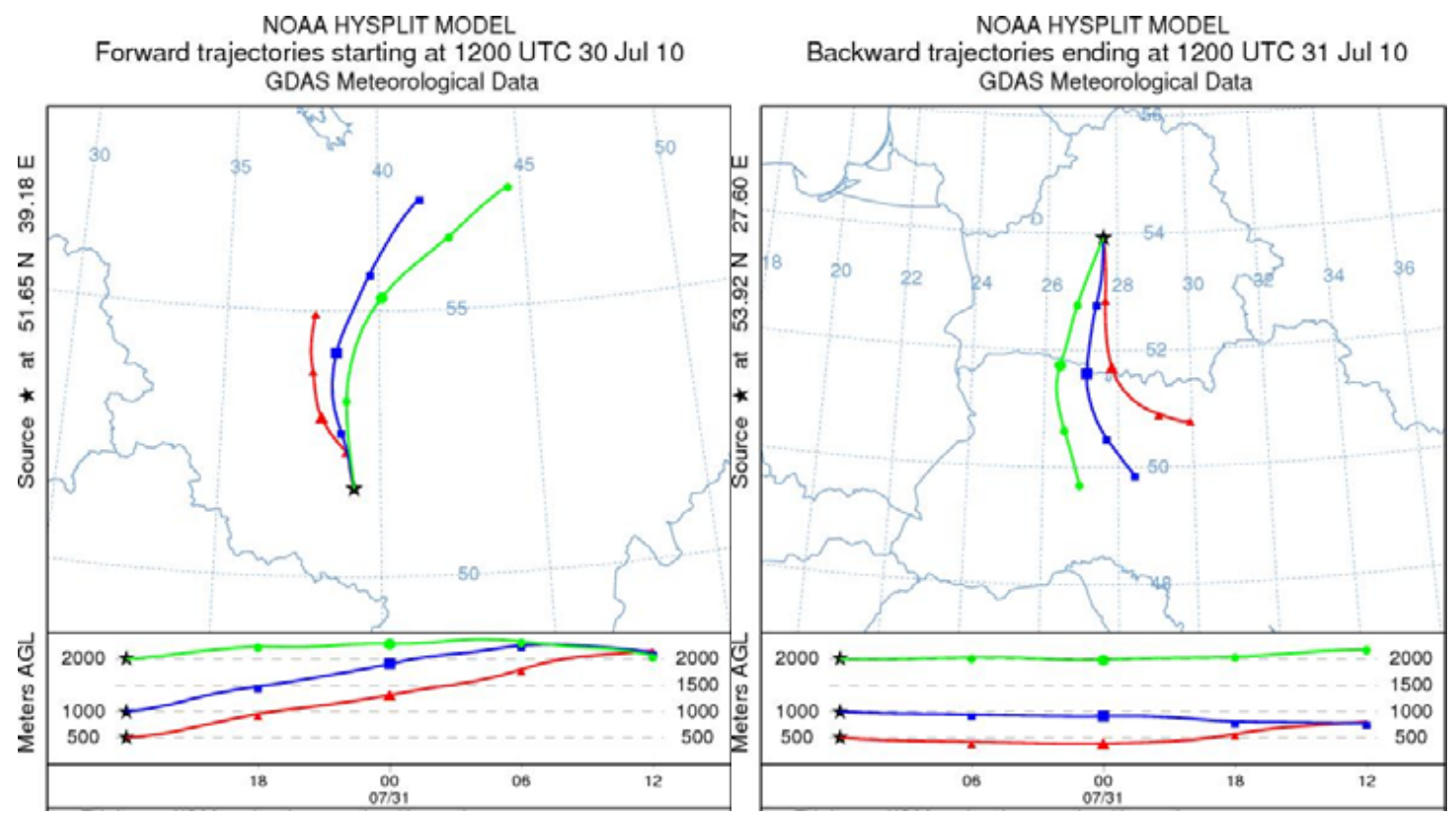

Fig. 9. Air flow trajectories for a $24 \mathrm{~h}$ time interval with $6 \mathrm{~h}$ temporal resolution obtained from the HYSPLIT model. Left: forward trajectories for air masses originating near the Voronezh Oblast starting on 30 July 2010 at 12:00 UTC; Right: backward trajectories of air masses reaching Belarus on 31 July 2010 at 12:00 UTC.

analysis. A large degree of day-to-day variability was observed during the overall fire episode in Moscow-MSU-MO and Yekaterinburg, with some days showing near-baseline AOD levels $(<0.2$ at $0.55 \mu \mathrm{m})$ for 2009 , whereas 2010 showed peaks in major tropical biomass burning regions. On 31 July, the AOD $(0.55 \mu \mathrm{m})$ was larger than 1.0 in 2010 (and in some cases even close to 1.8 ), whereas the corresponding AOD figure $(0.55 \mu \mathrm{m})$ for 2009 was less than 0.2. This demonstrated that the plume had already affected Central Russia. Additionally, the AOD measurements at some locations (Moscow-MSU-MO) were also strongly affected by the location of the fires relative to the wind direction and other meteorological factors after 1 August 2010. The AOD values during 6-10 August 2010 were also very high, with a large Ångström exponent, which implies that most of the aerosol was composed of small particles produced by biomass burning. Moscow was severely influenced by the wildfires on 7 and 8 August 2010; the AOD was greater than 4.5, which means that the visibility in many parts of the city was less than $100 \mathrm{~m}$. Based on the satellite images, the effect of the Russian wildfires decreased on 10 August compared with 9 August 2010; however, the ground-based observations show that the fire was still strongly affecting Moscow at that time. This is mainly due to different data recording times: the satellite images record information on the atmosphere in the afternoon, whereas the AERONET system records this information from 8:00 a.m. It can be concluded that the effect of the fire on Moscow began to decrease in the afternoon on 10 August 2010. Several observations indicate the decrease in the Ångström coefficient from approximately 2.1 for young smoke particles to smaller values as the distance from the source (and, consequently, the age of the air mass) increased (O'Neill et al., 2002). These observations support our interpretation of the biomass burning episode. Figure 8 shows that Central Russia (Yekaterinburg) was affected by the wildfire during the period from 31 July to 12 August; the AOD value for 2010 (which is larger than 1.0) is much higher than that for a similar period in 2009 (which is less than 0.2), and the Ångström exponent for 2010 is much larger than that for 2009. Based on the satellite observations, we cannot confirm whether the fire was still affecting Central Russia during 1315 August 2010. We found an effect during these days according to the AERONET observations; meteorological conditions were beneficial for the spread of pollution during the night of 12 August 2010. We cannot confirm from satellite observations alone whether the fire affected Eastern Russia during 7-10 August 2010. Figure 8 demonstrates that the AOD values were high during 6-9 August 2010, which suggests that the fire may have begun to affect Eastern Russian on 6 August 2010; however, the Ångström exponent values indicate that large particles were present into the atmosphere on 6 August 2010, possibly due to local emissions. We can confirm that the fire affected Eastern Russia during 7-9 August 2010 .

We also found that the Russian wildfires had serious effects on Finland on 8 August 2010 according to the AERONET observations. A south-eastern wind carried the Russian wildfire plumes into Eastern Europe. However, due 

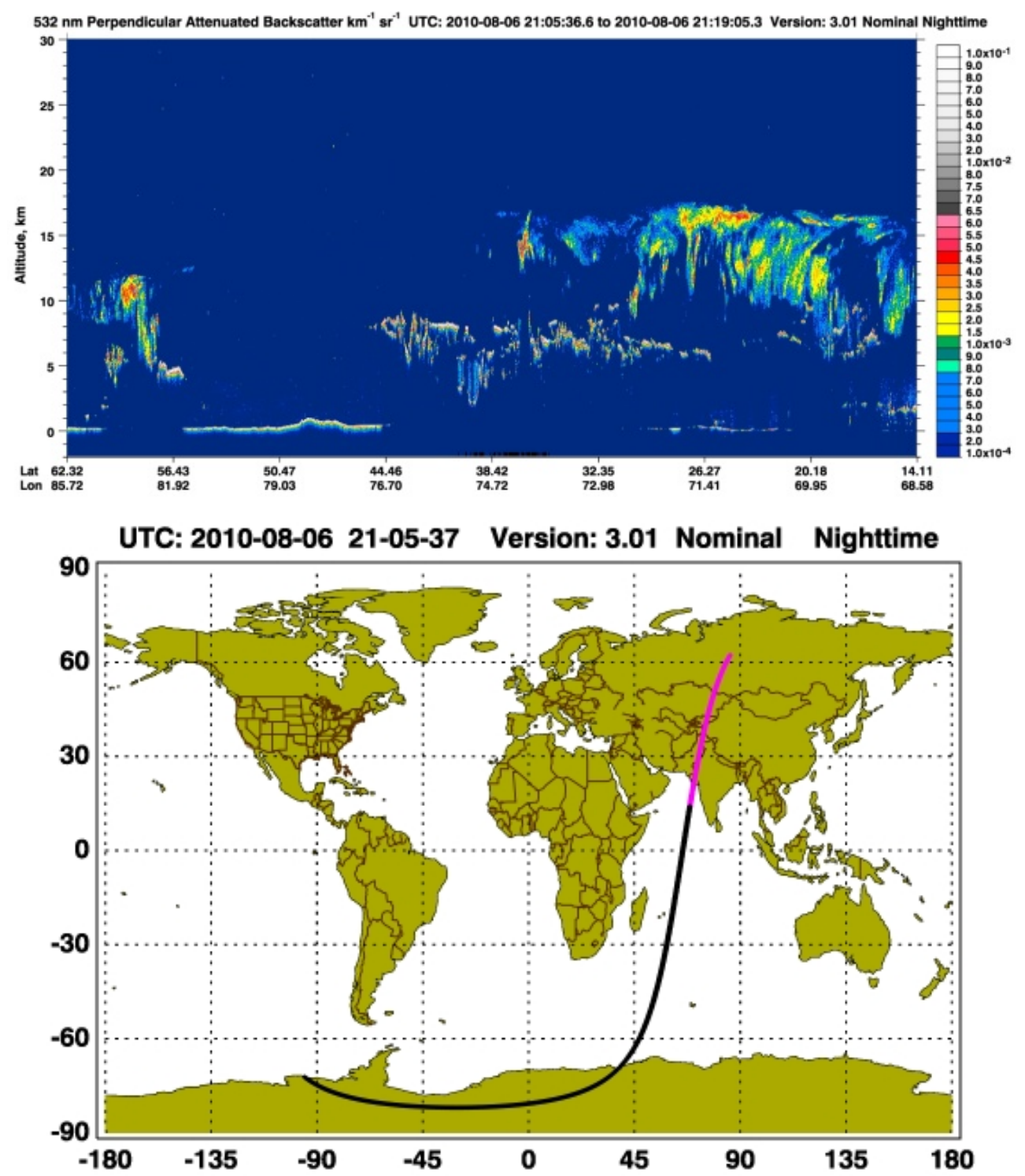

Fig. 10. CALIPSO measurements of aerosol extinction coefficient over Kyrgyzstan on 6 August 2010. Bottom: the orbit of CALIPSO.

to the south-westerly wind the effects of the smoke were diminished soon thereafter. Based on satellite observations, it was not possible to confirm whether the fire was still affecting Finland during 9-12 August 2010. In Estonia, the fire had a strong effect on 7 August 2010, as shown in Fig. 8. It is uncertain whether the fire was still affecting Estonia during 8-10 August and 13-15 August 2010. The AERONET observations indicate that the effect decreased significantly in the afternoon of 8 August; the AOD was over 0.15 before 12:00 UTC and 0.07 after 14:00 UTC. Figure 8 also demonstrates that the fire began to affect Estonia again on 14-15 August 2010. During 31 July 2010, the day of highest aerosol loading (approximate 0.7) over Minsk, the Ångström wavelength exponent, computed from the $440 \mathrm{~nm}$ and $870 \mathrm{~nm}$ channels, ranged from 0.5 to 1.0 , indicating the presence of mid-size particles. However, the effect of the Russian wildfires was clearly negligible given the air mass trajectories shown in Fig. 9, which indicate that local-scale phenomena had the greater influence. Industry and transport pollution from South Belarus may have caused the pollution. However, this is not the case for 3-10 August 2010, the period during which the satellite observations suggest that the fire affected Belarus. The AOD values for 14-15 August suggest that the fire began to affect Belarus during 14-15 August 2010, and these results are also consistent with the satellite data. Figure 8 indicates that the fire was still affecting Ukraine during 9-10 August 2010.

Data from three AERONET sites (IASBS, Issyk-Kul, and Lahore) located in Asia was collected to analyse the influence of the Russian wildfires on Asia. According to the 
Table 3. The effect of Russian wildfires on Russia and neighbouring countries in 2010, with different numbers representing different levels. Levels 1 to 5 stand for no effect, very little effect (a negligible effect), a possible effect, a certain effect and a strong effect, respectively.

\begin{tabular}{|c|c|c|c|c|c|c|c|c|c|c|}
\hline & Iran & Kyrgyzstan & Finland & Ukraine & Pakistan & Belarus & Russia-West & Russia-Middle & Russia-East & Estonia \\
\hline 31 July & 1 & 4 & 1 & 1 & 1 & 1 & 4 & 4 & 2 & 1 \\
\hline 1 August & 1 & 4 & 1 & 1 & 1 & 1 & 4 & 4 & 2 & 1 \\
\hline 2 August & 1 & 4 & 1 & 1 & 1 & 1 & 4 & 4 & 2 & 1 \\
\hline 3 August & 1 & 4 & 1 & 1 & 1 & 3 & 4 & 4 & 2 & 1 \\
\hline 4 August & 1 & 4 & 1 & 1 & 1 & 3 & 4 & 4 & 2 & 1 \\
\hline 5 August & 1 & 3 & 1 & 1 & 1 & 3 & 4 & 4 & 2 & 1 \\
\hline 6 August & 1 & 3 & 1 & 4 & 1 & 4 & 5 & 4 & 2 & 1 \\
\hline 7 August & 1 & 3 & 1 & 3 & 1 & 4 & 5 & 4 & 4 & 4 \\
\hline 8 August & 1 & 3 & 5 & 3 & 1 & 3 & 5 & 4 & 4 & 3 \\
\hline 9 August & 1 & 3 & 2 & 3 & 1 & 3 & 5 & 4 & 4 & 2 \\
\hline 10 August & 1 & 4 & 1 & 3 & 1 & 3 & 4 & 5 & 2 & 2 \\
\hline 11 August & 1 & 4 & 1 & 2 & 1 & 1 & 4 & 5 & 2 & 1 \\
\hline 12 August & 1 & 4 & 1 & 2 & 1 & 1 & 4 & 5 & 2 & 1 \\
\hline 13 August & 1 & 4 & 1 & 2 & 1 & 1 & 4 & 1 & 2 & 2 \\
\hline 14 August & 1 & 4 & 1 & 5 & 1 & 4 & 4 & 1 & 2 & 3 \\
\hline 15 August & 1 & 4 & 1 & 5 & 1 & 4 & 4 & 1 & 2 & 3 \\
\hline
\end{tabular}

satellite-derived AOD data, the wildfires had little effect on most of Asia. IASBS and Issyk-kul are at high elevation (see Table 1) where AOD values often much lower than at lower elevations. Because the Issyk-Kul station is located on the eastern edge of Kyrgyzstan, we can further analyse the effect of the Russian fires on Eastern Kyrgyzstan based on data indicating that the fire affected Kyrgyzstan form 31 July to 15 August 2010. Figure 8 demonstrates that the fire began to affect Eastern Kyrgyzstan on 3 August 2010 and that the greatest effects occurred on 5 August 2010. However, there are no values for 6-7 August, 2010. CALIPSO data were also collected so that we might make a more detailed analysis. Vertical distribution of AOD over Issyk-Kul from a CALIPSO overpass on 6 August 2010 was prepared. Figure 10 shows the aerosol extinction coefficient over Kyrgyzstan in August, 2010. We can see the vertical profile of aerosol at different levels. The aerosol extinction coefficient is much larger above $5 \mathrm{~km}$ than near the surface, which indicates that the pollutants emitted by the Russian wildfires were transported to higher levels Satellite-derived AOD and $\mathrm{PM}_{2.5}$ data suggest that the fires had little to no effect on Iran and Pakistan. However, the in situ observation showed that the AOD was much higher on days with large Ångström exponents, which implies that there could have been some effect on some days. Although there is no 2009 AERONET data for the IASBS sites, the values for 31 July 2010 were less than 0.05 , indicating a very low background level of 0.05 for those sites. Figure 1 shows that there were biomass burning episodes in Iran and Pakistan. The local emissions contributed significantly to the increase in AOD.

\section{Discussion and conclusions}

Extensive fire activities occurred during late July to August in 2010 over Western Russia. The effects on the local Atmos. Environ. and regional transport to Asia and Europe were analysed in this study using multiple satellite remote sensing products (MODIS AOD, $\mathrm{PM}_{2.5}$, CALIPSO AOD and $\mathrm{OMI} \mathrm{CO}_{2}, \mathrm{SO}_{2}, \mathrm{NO}_{2}$ ) and surface observation tools (AERONET AOD, Ångström exponent and in situ measurements of $\mathrm{PM}_{2.5}$ ) together with synoptic data. The heavy smoke plume had a significant effect on the local and regional concentration, especially in Western and Central Russia.

The smoke plumes from the Russian forest fires extended as far as Moscow and into Eastern Europe and Northern Asia. Moscow was seriously influenced by the wildfires from 31 July to 15 August, 2010 and especially from 6 to 9 August 2010. On 7 and 8 August 2010, the AOD was greater than 4.5 , and the visibility in many parts of Moscow was lower than $100 \mathrm{~m}$. The smoke aerosol contributed to the daily averaged surface $\mathrm{PM}_{2.5}$ concentration in Moscow, which exceeded levels of $500 \mu \mathrm{g} \mathrm{m}^{3}$. The plume moved toward the East and North-East toward Central Russia and Kyrgyzstan, which were thus affected by the fire. The effect on Central Russia and Kyrgyzstan lasted as long as the effect on Western Russia but was not as intense. For Central Russia, the greatest effect was seen during 10-12 August 2010. However, due to meteorological conditions, the effect decreased on $13 \mathrm{Au}-$ gust 2010, and there was basically no effect on Central Russia. The wildfires had a strong effect on Eastern Russia during 7-9 August 2010. For the eastern european countries, the wildfire had a strong effect in some cases for a short period 
of time, and the $\mathrm{PM}_{2.5}$ concentrations in the affected countries were 3-5 times their normal rates. On 8 August 2010, Finland was seriously affected by the plume; its $\mathrm{PM}_{2.5}$ concentrations exceeded $60 \mu \mathrm{g} \mathrm{m}^{3}$ (these $\mathrm{PM}_{2.5}$ concentrations are normally less than $15.4 \mu \mathrm{g} \mathrm{m}^{3}$ ). The fire affected Ukraine and Estonia during 7-9 August 2010. No effect was found in the other Asian countries such as Iran and Pakistan. The detailed results indicating the effect of the Russian wildfires on local and neighbouring countries are shown in Table 3, with different numbers representing different levels. Levels 1 to 5 stand for no effect, very little effect, a possible effect, a certain effect and a strong effect, respectively. This paper shows that the integration of multiple forms of remote sensing data and ground-based data, together with metrological data, constitutes a powerful tool for characterising plume transport. The behaviour of different atmospheric parameters as described in the paper is consistent and the analysis using satellite atmospheric parameters is in line with synoptic charts. Hence the different data sources are complementary and the results support each other.

Acknowledgements. This work was supported in part by the Ministry of Science and Technology (MOST), China, under Grant Nos. 2010CB950802, 2010CB950803 and 2008AA12Z109. MODIS data were made available by NASA MODIS LAADS. OMI data were accessed at http://disc.sci.gsfc.nasa.gov/. Many thanks are due to the PI investigators of the AERONET sites used in this paper. The authors would like to thank Hong Liao and Sijia Lou from the Institute of Atmospheric Physics, Chinese Academy of Sciences; Colette L. Heald from the Department of Atmospheric Science, Colorado State University; Bob Yantosca from the GEOS-Chem Support Team; and Qianqian Zhang from Tinghua University for their help with GEOS-Chem. Thanks to A. van Donkelaar and R. V. Martin of Department of Physics and Atmospheric Science, Dalhousie University, Halifax, Nova Scotia, Canada for the AOD-PM 2.5 conversion factors to relate our AOD retrievals to surface $\mathrm{PM}_{2.5}$. Thanks to Fumo Yang from the Graduate School of Chinese Academy of Sciences for assistance with methods of source apportionment; thanks to Ying Zhang from the Institute of Remote Sensing Applications, Chinese Academy of Sciences for help with WRF; thanks to Inger Utne from Norway, Mikhai Sofiev from FMI, and Wenche Aas from the Norwegian Institute for Air Research for their help with the in situ analysis of $\mathrm{PM}_{2.5}$ data; and thanks to Dave Larko from the Laboratory for Atmosphere Support at the NASA Goddard Space Flight Center for his help with the OMI data analysis. The contribution of Gerrit de Leeuw was in part supported by the the ESA-ESRIN project STSE-ALANIS Atmosphere Land Interaction Study, Theme 3 Aerosols.

Edited by: D. F. Prieto

\section{References}

Alleaume, S., Hely, C., Le Roux, J., Korontzi, S., Swap, R.J, Shugart, H. H., and Justice, C. O.: Using MODIS to evaluate heterogeneity of biomass burning in Southern African Savannahs a case study in Etosha, Int. J. Remote Sens., 26, 4219-4237, 2005.

Bartalev, S. A., Korovin, G. N., and Shlepak, B. V.: Assessments of Forest Fire Recognition, Using the NOAA AVHRR Radiometers, in: Proceedings of International Forum on Problems in Science, Technology and Education, Vol. II, Moscow, 22-25, 1977.

Baumer, D., Vogel, B., Versickm, S., Rinke, R., Mohlerm, O., and Schnaiter, M.: Relationship of visibility, aerosol optical thickness and aerosol size distribution in an ageing air mass over South-West Germany, Atmos. Environ., 42, 989-998, 2008.

Beirle, S., Platt, U., Wenig, M., and Wagner, T.: Weekly cycle of $\mathrm{NO}_{2}$ by GOME measurements: a signature of anthropogenic sources, Atmos. Chem. Phys., 3, 2225-2232, doi:10.5194/acp-32225-2003, 2003.

Bradley, A. V. and Millington, A. C.: Spatial and temporal scale issues in determining biomass burning regimes in Bolivia and Peru, Int. J. Remote Sens., 27, 2221-2253, 2006.

Bruzzone, L., Casadio, S., Cossu, R., Sini, F., and Zehner, C.: A system for monitoring $\mathrm{NO}_{2}$ emissions from biomass burning by using GOME and ATSR-2 data, Int. J. Remote Sens., 24, 17091721, 2003.

Conard, S. G. and Ivanova, G. A.: A Differential Approach to Numerical Assessment of Forest Fire Carbon Emissions, Lesovedenie (Forestry), 3, 28-35, 1988.

Crutzen, P. J. and M. O. Andrea: Biomass burning in the tropics: Impact on atmospheric chemistry and biogeochemical cycles, Science, 250, 1669-1678, 1990.

Drury, E., Jacob, D. J., Spurr, R. J. D., Wang, J., Shinozuka, Y., Anderson, B. E., Clarke, A. D., Dibb, J., Mcnaughton, C., and Weber, R.: Synthesis of satellite (MODIS), aircraft (ICARTT), and surface (IMPROVE, EPA-AQS, AERONET) aerosol observations over North America to improve MODIS aerosol retrievals and constrain surface aerosol concentrations and sources, J. Geophys. Res., 115, D14204, doi:10.1029/2009JD012629, 2010.

Elridge, R. G.: Climatic visibilities of the United States, J. Appl. Meteorol., 5, 227-282, 1986.

Field, R. D., van der Werf, G. R., Shen, S. S. P.: Human amplification of drought-induced biomass burning in Indonesia since 1960, Nat. Geosci., 2, 185-188, 2009.

Flowerdew, R. J. and Haigh, J. D.: An approximation to improve accuracy in the derivation of surface reflectances from multi-look satellite radiometers., Geophys. Res. Lett., 22, 1693-1696, 1995.

Freitas, S. R., Longo, K. M., Silva Dias, M. A. F., Silva Dias, P. L., Chatfield, R., Prins, E., Artaxo, P., Grell, G. A., and Recuero, F. S.: Monitoring the transport of biomass burning emissions in South America, Environ. Fluid Mech., 5, 135-167, doi:10.1007/s10652-005-0243-7, 2005.

Giglio, L., van der Werf, G. R., Randerson, J. T., Collatz, G. J., and Kasibhatla, P.: Global estimation of burned area using MODIS active fire observations, Atmos. Chem. Phys., 6, 957974, doi:10.5194/acp-6-957-2006, 2006.

Giglio, L., Randerson, J. T., van der Werf, G. R., Kasibhatla, P. S., Collatz, G. J., Morton, D. C., and DeFries, R. S.: Assessing variability and long-term trends in burned area by merging multiple satellite fire products, Biogeosciences, 7, 1171-1186, doi:10.5194/bg-7-1171-2010, 2010. 
Hadjimitsis, D. G., Clayton, C., and Toulio, L.: Retrieving visibility values using satellite remote sensing data, Phys. Chem. Earth, 35, 121-124, 2010.

Hoelzemann, J. J., Longo, K. M., Fonseca, R. M., do Rosario, N. M. E., Elbern, H., Freitas, S. R., and Pires, C.: Regional representativity of AERONET observation sites during the biomass burning season in South America determined by correlation studies with MODIS Aerosol Optical Depth, J. Geophys. Res., 114, D13301, doi:10.1029/2008JD010369, 2009.

Hsu, N. C., Tsay, S. C., King, M. D., and Herman, J. R.: Aerosol Properties over Bright Reflecting Source Regions, IEEE T. Geosci. Remote, 42, 557-569, 2004.

Ichoku, C., Giglio, L., Qooster, M. J., and Remer, L. A.: Global characterization of biomass-burning patterns using satellite measurements of fire radiative energy, Remote Sens. Environ., 112, 2950-2962, 2008.

Isaev, A. S., Korovin, G. N., Bartalev, S. A., Ershov, D. V., Janetos, A., Kasischke, E. S., Shugart, H. H., French, N. H. F., Orlick, B. E., and Murphy, T. L.: Using Remote Sensing to Assess Russian Forest Fire Carbon Emissions, Climatic Change, 55, 235-249, 2002.

Kaufman, Y. J., Tanre, D., Remer, L. A., Vermote, E. F., Chu, A., Holben, B. N.: Operational remote sensing of tropospheric aerosol over land from EOS moderate resolution imaging spectroradiometer, J. Geophys. Res., 102, 17051-17067, doi:10.1029/96JD03988, 1997.

Kim, S. W., Yoon, S. C., Jefferson, A., Ogren, J. A., Dutton, E. G., Won, J. G., Ghim, Y. S., Lee, B. I., and Han, J. S.: Aerosol optical, chemical an physical properties at Gosan Korea during Asian dust and pollution episodes in 2001, Atmos. Environ., 39, 39-50, 2005.

Kondratyev, K. Y.: Radiation in the atmosphere, Academic Press, New York and London, 1969.

Kundu, S., Kawamura, K., Andreae, T. W., Hoffer, A., and Andreae, M. O.: Molecular distributions of dicarboxylic acids, ketocarboxylic acids and $\alpha$-dicarbonyls in biomass burning aerosols: implications for photochemical production and degradation in smoke layers, Atmos. Chem. Phys., 10, 2209-2225, doi:10.5194/acp-10-2209-2010, 2010.

Lee, K. H., Kim, J. E., Kim, Y. J., Kim, J., and von HoyningenHuene, W.: Impact of the smoke aerosol from Russian forest fires on the atmospheris enviroment over Korea during May 2003, Atmos. Environ., 39, 85-99, 2005.

Levy, R. C., Remer, L. A., Mattoo, S., Vermote, E. F. and Kaufman, Y. J.: Second-generation operational algorithm: Retrieval of aerosol properties over land from inversion of Moderate Resolution Imaging Spectroradiometer spectral reflectance, J. Geophys. Res., 112, D13211, doi:10.1029/2006JD007811, 2007.

Liu, Y., Park, R. J., Jacob, D. J., Li, Q. B., Kilaru, V., and Sarnat J. A.: Mapping annual mean ground-level $\mathrm{PM}_{2.5}$ concentrations using Multiange Image Spectroradiometer aerosol optical thickness over the contiguous United States, J. Geophys. Res., 109, D22206, doi:10.1029/2004JD005025, 2004.

Liu, Y., Kahn, R. A., Chaloulakou, A., and Koutrakis, P.: Analysis of the impact of the forest fires in August 2007 on air quality of Athens using multi-sensor aerosol remote sensing data, meteorology and surface observations, Atmos. Environ., 43, 33103318, 2009.

Mei, L. L., Xue, Y., Xu, H., Guang, J., Li, Y. J., Wang, Y., Ai, J.
W., Qi , Y., and He, X. W.: Validation and analysis of optical thickness retrieval over land, I. J. Remote Sens., 33, 781-803, doi:10.1080/01431161.2011.577831, 2012.

Murdiyarso, D.: Policy options to reduce $\mathrm{CO}_{2}$ release resulting from deforestation and biomass burning in Indonesia, Chemosphere, 27, 1109-1120, 1993.

Nam, J., Wang, Y., Luo, C., and Chu, D. A.: Trans-Pacific transport of Asian dust and CO: accumulation of biomass burning CO in the subtropics and dipole structure of transport, Atmos. Chem. Phys., 10, 3297-3308, doi:10.5194/acp-10-3297-2010, 2010.

O’Neill, N. T., Eck, T. F.,Holben, B. N., Smirnov, A., Royer, A., Li, Z.: Optical properties of boreal forest fire smoke derived from sun photometry, J. Geophys. Res., 107, 4125, doi:10.1029/2001JD000877, 2002.

Palacios-Orueta, A., Parra, A., Chuvieco, E., and Carmona-Moreno, C.: Remote sensing and geographic information systems methods for global spatiotemporal modeling of biomass burning emissions: Assessment in the African continent, J. Geophys. Res., 109, D14S09, doi:10.1029/2004JD004734, 2004.

Palacios-Orueta, A., Chuvieco, E., Parra, A., and Carmona-Moreno, C.: Biomass buring emissions: A review of models using remotesensing data, Environ. Monit. Assess., 104, 189-209, 2005.

Prins, E. M. and Menzel, W. P.: Geostationary satellite detection of biomass burning in South America, Int. J. Remote Sens., 13, 2783-2799, 1992.

Reid, J., Hobbs, P., Ferek, R., Blake, D., Martins, J., Dunlap, M., and Liousse, C.: Physical, chemical, and optical properties of regional hazes dominated by smoke in Brazil, J. Geophys. Res., 103, 32059-32080, 1998.

Remer, L. A., Kaufman, Y. J., Tanre, D., Mattoo, S., Chu, D. A., Martins, J. V., Li, R. R., Ichoku, C., Levy, R. C., Kleidman, R. G., Eck, T. F., Vermote, E., and Holben, B. N.: The MODIS aerosol algorithm, products, and validation, J. Atmos. Sci., 62, 947-973, 2005.

Retalis, A., Hadjimitsis, D. G., Michaelides, S., Tymvios, F., Chrysoulakis, N., Clayton, C. R. I., and Themistocleous, K.: Comparison of aerosol optical thickness with in situ visibility data over Cyprus, Nat. Hazards Earth Syst. Sci., 10, 421-428, doi:10.5194/nhess-10-421-2010, 2010.

Ricardo, J., France, A., Brustet, J. M., and Fontan J.: Multispectral remote sensing of biomass burning in West Africa, J. Atmos. Chem., 22, 8-110, doi:10.1007/BF00708183, 1995.

Scholes, M. and Andreae, M. O.: Biogenic and pyrogenic emissions from Africa and their impact on the global atmosphere, Ambio, 29, 23-29, 2000.

Seinfeld J. H. and Pandis, S. N.: Atmospheric Chemistry and Physics: From Air Pollution to Climate Change, San Francisco: A Wiley-Interscience Publications, 719, 1998.

Taner, D. and Kaufman Y. J.: Remote sensing of aerosol properties over oceans using the MODIS/EOS spectral radiances, J. Geophys. Res., 102, 16971-16988, 1997.

Tang, J., Xue, Y., Yu, T., and Guan, Y.: Aerosol optical thickness determination by exploiting the synergy of TERRA and AQUA MODIS, Remote Sens. Environ., 94, 327-334, 2005.

Tansey, K., Gregoire, J. M., Defourny, P., Leigh, R., Pekel, J.F., van Bogaert, E., and Bartholome, E.: A new, global, multi-annual (2000-2007) burnt area product at $1 \mathrm{~km}$ resolution, Geophys. Res. Lett., 35, L01401, doi:10.1029/2007GL031567, 2008.

Trentmann, J., Andreae, M. O., Graf, H. F., Hobbs, P. V., Ottmar, R. 
D., and Trautmann, T.: Simulation of a biomass-burning plume - Comparison of model results with observations, J. Geophys. Res., 107, 4013-4028, doi:10.1029/2001JD000410, 2001.

van der A, R. J., Eskes, H. J., Boersma, K. F., van Noije, T. P. C., Van Roozendael, M., De Smedt, I., Peters, D. H. M. U., and Meijer. E. W.: Trends, seasonal variability and dominant $\mathrm{NO}_{\mathrm{x}}$ source derived from a ten year record of $\mathrm{NO}_{2}$ measure from space, $\mathrm{J}$. Geophys. Res., 113, D04302, doi:10.1029/2007JD009021, 2008. Van Donkelaar, A., Martin, R. V., and Park, R. J.: Estimating ground-level $\mathrm{PM}_{2.5}$ using aerosol optical depth determined from satellite remote sensing, J. Geophys. Res., 111, D21201, doi:10.1029/2005JD006996, 2006.

Van Donkelaar, A., Martin, R. V., Brauer, M., Kaha, R. A., Levy, R. C., and Verduzco, C.: Global Estimates of Ambient Fine Particulate Matter Concentrations from Satellite-Based Aerosol Optical Depth: Development and Application, Environ. Health Persp., $118,847-855,2010$

Varotsos, C. A. and Zellner, R.: A new modeling tool for the diffusion of gases in ice or amorphous binary mixture in the polar stratosphere and the upper troposphere, Atmos. Chem. Phys., 10, 3099-3105, doi:10.5194/acp-10-3099-2010, 2010.
Vermote, E. F., Tanré, D., Deuzé, J. L., Herman, M., and Morcrette, J. J.: Second simulation of the satellite signal in the solar spectrum: user manual, University of Maryland/Laboratoire d'Optique Atmospherique, 1994.

Westphal, D. L. and Toon, O. B.: Simulations of microphysical radiative and dynamical process in a continental-scale forest fire smoke plume, J. Geophys. Res., 96, 22379-22400, 1991.

Witham C. and Manning A.: Impacts of Russian biomass burning on UK air quality, Atmos. Environ., 41, 8075-8090, 2007.

World Meteorological Organization (WMO): Manual on the Global Observing System, WMO-No. 544, Geneva, 2003.

Xue, Y. and Cracknell, A. P.: Operational bi-angle approach to retrieve the Earth surface albedo from AVHRR data in the visible band, Int. J. Remote Sens., 16, 417-429, 1995.

Xue, Y., Guo, J. P., and Zhang, X. Y.: Aerosol Optical Thickness Retrieval over non-Lambertian Land Surface with Synergistic Use of AATSR Radiance Measurements and MODIS Derived Albedo Model Parameters, Atmos. Res., 93, 736-746, 2009.

Zakey, A. S., Abdelwahab, M. M., and Makar, P. A.: Atmospheric turbidity over Egypt, Atmos. Environ., 38, 1579-1591, 2004. 